\title{
EXPECTATIONS AND EXPATRIATIONS: TRACING THE CAUSES AND CONSEQUENCES OF CORPORATE INVERSIONS
}

\author{
Mihir A. Desai \\ James R. Hines Jr. \\ Working Paper 9057 \\ http://www.nber.org/papers/w9057 \\ NATIONAL BUREAU OF ECONOMIC RESEARCH \\ 1050 Massachusetts Avenue \\ Cambridge, MA 02138 \\ July 2002
}

We thank Mark Veblen for excellent research assistance, and Reuven Avi-Yonah, Peter Merrill, Adair Morse, and Joel Slemrod for helpful comments on earlier drafts. Financial support from the Lois and Bruce Zenkel Research Fund at the University of Michigan and the Division of Research at Harvard Business School is gratefully acknowledged. The views expressed herein are those of the authors and not necessarily those of the National Bureau of Economic Research.

(C) 2002 by Mihir A. Desai and James R. Hines Jr. All rights reserved. Short sections of text, not to exceed two paragraphs, may be quoted without explicit permission provided that full credit, including (C) notice, is given to the source. 
Expectations and Expatriations: Tracing the Causes

and Consequences of Corporate Inversions

Mihir A. Desai and James R. Hines Jr.

NBER Working Paper No. 9057

July 2002

JEL No. H87, H25, F23, G34

\begin{abstract}
This paper investigates the determinants of corporate expatriations. American corporations that seek to avoid U.S. taxes on their foreign incomes can do so by becoming foreign corporations, typically by "inverting" the corporate structure, so that the foreign subsidiary becomes the parent company and U.S. parent company becomes a subsidiary. Three types of evidence are considered in order to understand this rapidly growing practice. First, an analysis of the market reaction to Stanley Works's expatriation decision implies that market participants expect its foreign inversion to be accompanied by a reduction in tax liabilities on U.S. source income, since savings associated with the taxation of foreign income alone cannot account for the changed valuations. Second, statistical evidence indicates that large firms, those with extensive foreign assets, and those with considerable debt are the most likely to expatriate suggesting that U.S. taxation of foreign income, including the interest expense allocation rules, significantly affect inversions. Third, share prices rise by an average of 1.7 percent in response to expatriation announcements. Ten percent higher leverage ratios are associated with 0.7 percent greater market reactions to expatriations, reflecting the benefit of avoiding the U.S. rules concerning interest expense allocation. Shares of inverting companies typically stand at only 88 percent of their average values of the previous year, and every ten percent of prior share price appreciation is associated with 1.1 percent greater market reaction to an inversion announcement. Taken together, these patterns suggest that managers maximize shareholder wealth rather than share prices, avoiding expatriations unless future tax savings - including reduced costs of repatriation taxes and expense allocation, and the benefits of enhanced worldwide tax planning opportunities - more than compensate for current capital gains tax liabilities.
\end{abstract}

Mihir A. Desai

Harvard Business School

Morgan 363, Soldiers Field

Boston, MA 02163

and NBER

mdesai@hbs.edu
James R. Hines Jr.

University of Michigan

Business School

701 Tappan Street

Ann Arbor, MI 48109-1234

and NBER

jrhines@umich.edu 


\section{Introduction}

There is considerable confusion over the attributes necessary for a corporation located in the United States to be considered an "American" company, particularly insofar as nationality is thought to carry with it any entitlement to special treatment. Manufacturing production is typically integrated internationally, so multinational firms headquartered in the United States are likely to purchase large fractions of their inputs from foreign suppliers, sell much of their output to foreign buyers, and in the process often employ more labor and capital in foreign countries than they do in America. ${ }^{1}$ This observation prompts some observers to question the wisdom of government policies directed at assisting those American companies with extensive global operations, ${ }^{2}$ while others take exactly the opposite view, arguing that international business mobility makes it essential for governments to do everything they reasonably can in order to make their locations attractive to multinational businesses. ${ }^{3}$

Taxation is one arena in which nationality has clear consequences. Home governments are entitled to tax the foreign incomes of their resident companies, and they do so to differing degrees. One consequence of the U.S. tax system is that a corporation considered to be American for tax purposes will typically face greater tax obligations on its foreign income than would the same company if it were considered to be, say, German for tax purposes. Tax authorities are keenly interested in the nationality of their companies for the simple reason that, if a multinational corporation is Japanese for tax purposes, then its foreign profits are subject to taxation by Japan, while if the same corporation were American, then the United States would receive any taxes due on foreign profits.

From a legal standpoint, the definition of American tax residence is reasonably straightforward: a corporation is "American" for tax purposes if it is incorporated in the United States. Firms choose their sites of incorporation, and, under current U.S. law, a company need not produce or sell anything in the country that serves as its tax home. As a result, there can be strong incentives to select incorporation sites that offer the most attractive tax benefits. The

\footnotetext{
${ }^{1}$ Consider Ford Motor Company, a household name in the United States. Ford's 10-K filing of March 28, 2002 indicates that, in 2001, Ford had 165,512 employees in the United States and 188,919 employees in other countries.

${ }^{2}$ See, for example, Reich (1990).

${ }^{3}$ See, for example, Hufbauer (1992).
} 
United States tends to fare poorly in such calculations, since American companies owe taxes to the United States on their foreign incomes, while companies based in numerous other countries, including Germany, the Netherlands, Canada, France, not to mention most tax havens, owe little or no tax to their home governments on any foreign income. ${ }^{4}$

These national differences create opportunities for American companies with foreign income to reduce their tax obligations by expatriating, thereby shedding their American identities and becoming foreign corporations. This transformation is accomplished by reincorporating in an appropriate foreign location, such as Bermuda or the Cayman Islands, typically by having a firm's foreign subsidiary exchange its shares for those of the American parent company. Individual shareholders, who previously owned shares of the American parent company, will then own shares of the foreign (parent) company, which owns the American company. These transactions are commonly referred to as "inversions," since their impact is to invert the corporate structure: the erstwhile subsidiary becomes the parent, and the erstwhile parent becomes the subsidiary. American corporations have undertaken several well-publicized inversions in recent years, and the rate at which they do so continues to rise. Indeed, seven members of the Standard \& Poor's 500 index have expatriated, or have announced plans to do so, and there are reportedly several others considering such inversions.

The purpose of this paper is to analyze the economic factors associated with corporate expatriations that take the form of inversions. This task is complicated by the fact that inversions, while growing in popularity, are still quite uncommon, so it is possible to obtain reliable information on only two dozen or so inverting companies. Accordingly, the paper employs three distinct methodologies - an analysis of market reactions to one announced expatriation, a statistical analysis of the factors that lead to decisions to expatriate, and an event study analysis of reactions to expatriations - to understand the motivations behind expatriations. As is typical of case studies, the analysis of the announced expatriation of Stanley Works is open to multiple interpretations; nevertheless, it offers suggestive evidence that market participants raised their expectations of future cash flows by more than could be justified by reduced repatriation taxes and enhanced ability to utilize interest tax shields. This analysis provides some

${ }^{4}$ See, for example, Collins and Shackelford (1995), who compare effective tax rates for otherwise-identical multinational firms based in the United States, Canada, Japan, and the United Kingdom. Kramer and Hufbauer (1975) 
limited foundation for fears that expatriations may be associated with the desire, and the expectation, that U.S. tax obligations on U.S.-source income will be reduced subsequent to an expatriation.

The statistical analysis of expatriations suggests that U.S. tax liabilities on foreign-source income are associated with the decision to undertake a foreign inversion. The probability of inverting is increasing in firm size and in the share of firm assets located abroad. Heavily leveraged firms are the most likely to expatriate, as are those operating in low-tax foreign countries. Since the U.S. system of taxing the worldwide incomes of American companies is particularly costly for firms with sizable interest expenses, as well as firms facing low foreign tax rates, this behavior is consistent with allocation rules playing an important role in the decision to give up U.S. identity.

The third part of the empirical analysis considers stock price reactions to inversion announcements. Stock prices react (on average) positively to announcements of plans to invert, with prices appreciating by 1.7 percent over a five-day window centered on inversion announcements. This stock price appreciation is considerably more pronounced for firms that have appreciated in value over the previous year, and whose shareholders therefore incur considerable capital gains liabilities when required to tender their shares (in exchanging them for new shares) as part of the inversion process. Firms that are heavily leveraged, and which therefore lose the ability to claim foreign tax credits they would need if American-owned, likewise exhibit positive price reactions upon inversion. Other measurable variables, such as average foreign tax rates, have little discernable effects on price reactions to inversion announcements, though the paucity of data makes it difficult to draw strong conclusions from this evidence.

These findings suggest that firms consider the forced capital gains realization, and consequent capital gains tax burden imposed on shareholders, in deciding whether or not to expatriate. The U.S. principle of taxing the worldwide incomes of American companies, together with the various quirky features of the system, means that many American companies would benefit from having foreign rather than American identity for tax purposes. What

offer an early forecast that such differences could encourage American firms with foreign income to expatriate. 
prevents a wholesale expatriation of corporate America is therefore either a reluctance to act on the basis of tax incentives, or else that costs of inverting exceed the potential benefits. A major cost of expatriation is that owners of inverting firms must recognize capital gains on stock appreciation since time of purchase; the magnitude of this cost depends, therefore, on a company's history of share price appreciation. For firms whose shares have appreciated significantly in value, it follows that expatriation is profitable only if the future gains from avoiding U.S. taxation of foreign income are so large that they more than offset the current capital gains tax liability for shareholders. The evidence that firms with significant prior share price appreciation exhibit the strongest positive price reactions to inversion implies that managers contemplating expatriation are generally sensitive to the tax burdens they impose on shareholders and these managers are maximizing shareholder wealth rather than share prices. If managers were maximizing share prices instead of shareholder wealth, there would be no taxbased counterweight to the perceived benefits of expatriation. These results suggest that a natural brake on the tide of inversions, and a corresponding selection mechanism, is operative with respect to expatriations.

Section two of the paper reviews the U.S. system of taxing the international income of American companies. Section three identifies the incentives that companies face to expatriate, and the costs that they incur in doing so. Section four takes an in-depth look at the experience of Stanley Works, an American company that has announced plans to expatriate through an inversion. Section five evaluates the factors that lead companies to invert, analyzing a large sample of publicly traded firms. Section six analyzes stock price reactions to inversion announcements. Section seven is the conclusion.

\section{The taxation of foreign income $e^{5}$}

The taxation of international transactions differs from the taxation of domestic economic activity primarily due to the complications that stem from the taxation of the same income by

multiple governments. In the absence of double tax relief, the implications of multiple taxation are potentially quite severe, since national tax rates are high enough to eliminate, or at least greatly discourage, most international business activity if applied two or more times to the same income. 
Almost all countries tax income generated by economic activity that takes place within their borders. In addition, many countries - including the United States - tax the foreign incomes of their residents. In order to prevent double taxation of the foreign income of Americans, U.S. law permits taxpayers to claim foreign tax credits for income taxes (and related taxes) paid to foreign governments. ${ }^{6}$ These foreign tax credits are used to offset U.S. tax liabilities that would otherwise be due on foreign-source income. The U.S. corporate tax rate is currently 35 percent, so an American corporation that earns $\$ 100$ in a foreign country with a 10 percent tax rate pays taxes of $\$ 10$ to the foreign government and $\$ 25$ to the U.S. government, since its U.S. corporate tax liability of $\$ 35$ (35 percent of $\$ 100$ ) is reduced to $\$ 25$ by the foreign tax credit of $\$ 10$.

Americans are permitted to defer any U.S. tax liabilities on certain unrepatriated foreign profits until they receive such profits in the form of dividends. ${ }^{7}$ This deferral is available only on the active business profits of American-owned foreign affiliates that are separately incorporated as subsidiaries in foreign countries. The profits of unincorporated foreign businesses, such as those of American-owned branch banks in other countries, are taxed immediately by the United States.

To illustrate deferral, consider the case of a subsidiary of an American company that earns $\$ 500$ in a foreign country with a 20 percent tax rate. This subsidiary pays taxes of $\$ 100$ to the foreign country (20 percent of \$500), and might remit \$100 in dividends to its parent U.S. company, using the remaining $\$ 300$ (\$500 - \$100 of taxes - \$100 of dividends) to reinvest in its own, foreign, operations. The American parent firm must then pay U.S. taxes on the $\$ 100$ of dividends it receives (and is eligible to claim a foreign tax credit for the foreign income taxes its subsidiary paid on the $\$ 100) .{ }^{8}$ But the American firm is not required to pay U.S. taxes on any part of the $\$ 300$ that the subsidiary earns abroad and does not remit to its parent company. If, however,

\footnotetext{
${ }^{5}$ Some parts of this brief description of international tax rules and evidence of behavioral responses to international taxation are excerpted from Hines (1997, 1999) and Hines and Hubbard (1995).

${ }^{6}$ The United States is not alone in taxing the worldwide income of its residents while permitting them to claim foreign tax credits. Other countries with such systems include Greece, Italy, Japan, Norway, and the United Kingdom. Under U.S. law, taxpayers may claim foreign tax credits for taxes paid by foreign firms of which they own at least 10 percent, and only those taxes that qualify as income taxes are creditable.

${ }^{7}$ Deferral of home-country taxation of the unrepatriated profits of foreign subsidiaries is a common feature of systems that tax foreign incomes. Other countries that permit this kind of deferral include Canada, Denmark, France, Germany, Japan, Norway, Pakistan, and the United Kingdom.

${ }^{8}$ In this example, the parent firm is eligible to claim a foreign tax credit of $\$ 25$, representing the product of foreign taxes paid by its subsidiary and the subsidiary's ratio of dividends to after-tax profits $[\$ 100 \times(\$ 100 / \$ 400)=\$ 25]$.
} 
the subsidiary were to pay a dividend of $\$ 300$ the following year, the firm would then be required to pay U.S. tax (after proper allowance for foreign tax credits) on that amount.

U.S. tax law contains provisions designed to prevent American firms from delaying the repatriation of lightly-taxed foreign earnings. These tax provisions apply to controlled foreign corporations, which are foreign corporations owned more than 50 percent by American individuals or corporations who hold stakes of at least 10 percent each. Under the Subpart F provisions of U.S. law, some foreign income of controlled foreign corporations is "deemed distributed," and therefore immediately taxable by the United States, even if not repatriated as dividend payments to American parent firms. ${ }^{9}$

Since the foreign tax credit is intended to alleviate international double taxation, and not to reduce U.S. tax liabilities on profits earned within the United States, the foreign tax credit is limited to U.S. tax liability on foreign-source income. For example, an American firm with $\$ 200$ of foreign income that faces a U.S. tax rate of 35 percent has a foreign tax credit limit of $\$ 70$ (35 percent of $\$ 200$ ). If the firm pays foreign income taxes of less than $\$ 70$, then the firm would be entitled to claim foreign tax credits for all of its foreign taxes paid. If, however, the firm pays $\$ 90$ of foreign taxes, then it would be permitted to claim no more than $\$ 70$ of foreign tax credits.

Taxpayers whose foreign tax payments exceed the foreign tax credit limit are said to have "excess foreign tax credits;" the excess foreign tax credits represent the portion of their foreign tax payments that exceed the U.S. tax liabilities generated by their foreign incomes. Taxpayers whose foreign tax payments are smaller than their foreign tax credit limits are said to have "deficit foreign tax credits." American law permits taxpayers to use excess foreign tax credits in one year to reduce their U.S. tax obligations on foreign source income in either of the two previous years or in any of the following five years. ${ }^{10}$

\footnotetext{
${ }^{9}$ Subpart $\mathrm{F}$ income consists of income from passive investments (such as interest and dividends received from investments in securities), foreign base company income (that arises from using a foreign affiliate as a conduit for certain types of international transactions), income that is invested in United States property, money used offshore to insure risks in the United States, and money used to pay bribes to foreign government officials. American firms with foreign subsidiaries that earn profits through most types of active business operations, and that subsequently reinvest those profits in active lines of business, are not subject to the Subpart F rules, and are therefore able to defer U.S. tax liability on their foreign profits until they choose to remit dividends at a later date.

${ }^{10}$ Foreign tax credits are not adjusted for inflation, so are generally the most valuable if claimed as soon as possible. Barring unusual circumstances, firms apply their foreign tax credits against future years only when unable to apply them against either of the previous two years. Firms paying the corporate alternative minimum tax (AMT) are
} 
In practice, the calculation of the foreign tax credit limit entails certain additional complications, the first of which is that total worldwide foreign income is used to calculate the foreign tax credit limit. This method of calculating the foreign tax credit limit is known as "worldwide averaging." A taxpayer has excess foreign tax credits if the sum of worldwide foreign income tax payments exceeds this limit, subject to the requirement that income is segregated into functional "baskets" for the purpose of this calculation. ${ }^{11}$

A second, and very important, aspect of the foreign tax credit calculation is the way in which it is affected by expenses incurred in the United States. Firms with certain types of taxdeductible expenses, particularly interest charges, expenditures on research and development, and general administrative and overhead expenses, are required to allocate fractions of these expenses between domestic and foreign source. The concept underlying this allocation process is that raising investment capital, producing innovations, and managing firm operations all contribute to the worldwide income of the firm. The intention of the U.S. allocation rules is to retain the tax benefits of the deductibility of such expenses against domestic income only for the portion of expenses that contribute to producing income that is taxable by the United States.

U.S. tax rules attempt to implement this principle by assigning a certain fraction of general expense items to have domestic source, with the rest being assigned to foreign source, based on arcane and ever-changing formulas. Expenses that are assigned to foreign source reduce the magnitude of foreign income for the purpose of calculating the foreign tax credit limit, which is costly for firms with excess foreign tax credits, and not costly for firms with deficit foreign tax credits. Interest expenses are allocated between domestic and foreign source based on fractions of assets located inside and outside the United States, ${ }^{12}$ while R\&D and other expenses are allocated based partly on place of performance and partly on relative foreign and domestic sales. ${ }^{13}$ Since

\footnotetext{
subject to the same rules, with the added restriction that the combination of net operating loss deductions and foreign tax credits cannot reduce AMT liabilities by more than 90 percent. It is noteworthy that, since the AMT rate is only 20 percent, firms subject to the AMT are considerably more likely to have excess foreign tax credits than are firms that pay the regular corporate tax.

${ }^{11}$ The "baskets" distinguish general active income from passive income, petroleum income, shipping income, and some other income categories, thereby, e.g., preventing taxpayers from using credits for taxes paid at high rates on petroleum income to reduce U.S. taxation of other active income. Desai and Hines (1999) analyze some of the impact of the U.S. "basket" rules.

${ }^{12}$ See Froot and Hines (1995) for a history, and more complete description, of the interest expense allocation rules, and an analysis of their impact on borrowing, leasing, and investment behavior.

${ }^{13}$ See Hines (1993) for an analysis of the impact of the R\&D expense allocation rules.
} 
interest expense is typically a firm's largest allocable expense, firms with heavily-taxed foreign income and considerable U.S. interest expenses are likely to incur significant costs associated with the inability to receive the full benefits of interest expense deductions.

The United States imposes withholding taxes on cross-border dividend, interest, and royalty payments to recipients in other countries. These royalty tax rates are frequently reduced according to the terms of bilateral tax treaties. For example, the United States imposes a 30 percent tax on interest payments to related parties resident abroad, but this rate is reduced, typically to zero, when recipients reside in countries with whom the United States has tax treaties in force.

\section{Expatriation in practice}

This section reviews the U.S. tax treatment of expatriations, and the incentives for which the U.S. tax system is responsible. ${ }^{14}$

\subsection{Expatriation mechanics}

An expatriation is accomplished by removing foreign assets and foreign business activity from ownership by an American corporation, thereby effectively eliminating U.S. taxes on any income they generate. Figure 1 graphically depicts the fundamentals of a corporate inversion, contrasting the pre-inversion ownership structure (left panel) to the post-inversion ownership structure (right panel). Prior to inverting, dividends from foreign operations are received by the American parent company, while subsequent to the inversion, dividends from foreign operations, as well as those from American operations, are received by the Bermuda (in this example) parent company. This structure is beneficial as long as any withholding taxes or other costs associated with dividend payments to Bermuda (which has no corporate income tax) are less than the costs associated with U.S. taxation of foreign income.

U.S. law generally requires foreign inversions to be recognition events for capital gains tax purposes, meaning that taxpayers will incur capital gains tax liabilities for any previously unrecognized gains. The nature of the capital gains taxes triggered by inversions depends on the

\footnotetext{
${ }^{14}$ In the interest of brevity and readability, the discussion of applicable tax law is somewhat general and quite condensed; more detailed coverage is available from various other sources, including the New York State Bar Association Tax Section (2002), the United States Department of the Treasury (2002), and Thompson (2002).
} 
way in which the inversion is structured; there are several possibilities, falling into two general categories which are depicted in Figure 2. In a taxable stock transfer, the new foreign parent company effectively exchanges its own shares for shares of the American company, a transaction that requires individual and other shareholders to recognize capital gains equal to the difference between fair market values of the shares and tax basis. At the conclusion of such a transfer, shareholders own stakes in the new foreign parent company, and the American operations are typically organized as a subsidiary of the new foreign parent. In an asset transaction, the new foreign parent company acquires an American firm's assets, thereby triggering taxes on capital gains at the corporate level equal to the difference between fair market value and basis. There are variants, including drop down transactions, that entail a combination of these two transactions, and associated capital gains tax liabilities at both the individual shareholder and U.S. corporate level.

Table 1 provides details on selected corporate expatriations over the last twenty years. While not an exhaustive list (due to the spotty coverage of historic inversion data, and the constant flow of current inversions), Table 1 captures the larger and more well-known corporate expatriations and their details. For each inverting company, Table 1 provides an announcement date, the destination of the inverting firm, the nature of the transaction, the market value at announcement, and a description of the company's business. Inspection of Table 1 provides some evidence on general trends. First, expatriating companies were historically dominated by the oil and gas and reinsurance businesses, while recent expatriates appear to be drawn from a more general distribution of American industrial companies, with several companies being market leaders in their business segments. Indeed, seven firms among the Standard Poor's 500 have expatriated, or are in the process of expatriating. ${ }^{15}$

The expatriations announced in the last twelve months that are listed in Table 1 combine for over \$25 billion in market capitalization at the time of announcement. While the transactions listed in Table 1 are dominated by taxable stock transfers, several other forms are included in the table, including subsidiary spin-offs, subsidiary initial public offerings, and asset transfers. Even among the taxable stock transfers, several are related to M\&A activity, whereby the inversion was accomplished through the acquisition of a preexisting entity rather than a pure expatriation into a new entity. Finally, two expatriations that represent the initial capitalization of companies abroad

\footnotetext{
${ }^{15}$ These S\&P 500 firms are Cooper, Ingersoll Rand, Nabors, Noble, Stanley, Transocean and Tyco.
} 
- Accenture and Seagate - are listed separately at the bottom of Table 1 as non-inversion expatriations.

\subsection{Incentives to expatriate}

Firms that expatriate remain subject to U.S. taxation of their U.S. income, since the American subsidiary under the new corporate structure is taxed as a U.S. corporation. The tax incentives for an American firm to expatriate can therefore be organized around $(i)$ the tax consequences that arise from no longer being subject to rules arising from the U.S. treatment of foreign source income, (ii) the tax consequences that arise from triggering capital gains at the firm level or shareholder level, and (iii) the tax consequences that arise from enhanced opportunities to relocate profits worldwide in a tax-advantaged way after an expatriation. ${ }^{16}$

The tax benefits of expatriating that relate to the U.S. treatment of foreign source income can be construed to have two distinct components. First, repatriation taxes, and costly actions taken to avoid repatriation taxes, would be avoided upon expatriation. ${ }^{17}$ These savings, and the restructuring of worldwide operations such that non-U.S. operations would avoid repatriation taxes and the encumbrances associated with Subpart F, are the most widely cited reasons for expatriating. Separately, and as highlighted above, expense allocation rules, including those related to the allocation of interest expense to foreign source income, can provide incentives to expatriate. By expatriating in a way that removes foreign assets from U.S. ownership, it is possible to receive the full benefits of tax shields associated with interest expenses that might not be as valuable currently due to a firm's excess foreign tax credit status.

Many of the expatriations profiled in Table 1 are also characterized by a realization event whereby capital gains are recognized at the shareholder or firm level. A primary tax cost associated with such expatriations is the capital gains tax liability that would otherwise have been deferred or possibly avoided altogether. Given that most expatriations are structured as taxable stock transfers that trigger liabilities at the shareholder level, the price path of a firm's stock would

\footnotetext{
${ }^{16}$ Separately, there may be differences in corporate governance and other national regulations that may provide managers with incentives that go beyond the scope of this paper.

${ }^{17}$ See Hines and Hubbard (1990), Altshuler, Newlon and Randolph (1995) and Desai, Foley and Hines (2001) for analyses of the tax sensitivities of dividend repatriations and Subpart F income recognition, and the associated efficiency costs.
} 
determine the tax costs shareholders incur as a result of expatriating. A second potential tax cost associated with expatriating is withholding taxes on subsequent payments to the new foreign parent company, the avoidance of which requires careful choice of new corporate home. ${ }^{18}$

Finally, an expatriating firm and its shareholders may perceive gains from increased flexibility with respect to the worldwide allocation of taxable profits. This increased flexibility pertains to the location of profits within foreign and domestic operations. Within their foreign operations, the foreign tax credit and the potential repatriation taxes a firm faces when bringing income home to the United States limits the returns to relocating profits from high-tax to low-tax jurisdictions. ${ }^{19}$ Given that this barrier is removed, and an expatriating firm therefore no longer faces a residual repatriation tax, incentives to be more aggressive in their structuring of worldwide operations would also increase, possibly resulting in increased after-tax cash flows. Similarly, an expatriating firm may become more aggressive with respect to relocating its U.S. income to the tax haven to which they are expatriating. While limits on such activity exist in U.S. tax law, the structuring of debt contracts with the new parents in tax haven countries may allow for reduced domestic tax obligations - sometimes referred to as interest stripping. ${ }^{20}$ Interest stripping entails financing a tax haven parent company's ownership of its American subsidiary largely with debt, thereby generating interest deductions against U.S. taxable income. The resulting interest income

\footnotetext{
${ }^{18}$ Since many inversions involve reincorporating in countries with whom the United States does not have tax treaties, it has been common practice to obtain treaty benefits (a five percent withholding tax rate on dividend payments from the United States, and no withholding taxes on interest) by having the foreign parent company managed and controlled in Barbados, with whom the United States does have a tax treaty. Barbados, in turn, imposes a small tax (of between one and 2.5 percent) on the foreign incomes of such companies.

${ }^{19}$ Profit location is affected by all aspects of a firm's foreign operations, including investment, financing, and the nature of intra-firm transactions. There is ample evidence that home-country taxation influences patterns of foreign investment (Hines (1996), Hines (2001), Desai, Foley, and Hines (2002)), financing (Hines (1994), Grubert (1998)), reported profitability (Desai, Foley, and Hines (2002)), organizational form (Desai and Hines (1999)), and foreign tax avoidance (Grubert (2001), Hines (2001)). The theoretical consequences of this function of the foreign tax credit system are highlighted in Gordon (1992); for a survey of these issues, see Hines (1999) and Gordon and Hines (forthcoming).

${ }^{20}$ These limits include the requirement (section 482) that transactions between related parties be conducted at arm'slength prices, meaning the prices that unrelated parties would or should use for the same transactions. In practice, this prevents a foreign parent company from charging excessive (tax-deductible) interest on a loan to its American subsidiary. Thin capitalization rules (section 163(j)) further limit the deductibility of interest payable to related foreign lenders to 50 percent of adjusted taxable income, whenever the American subsidiary's debt-equity ratio exceeds 1.5. Of course, there are many fewer limits on the ability of an American corporation to borrow from unrelated domestic parties, thereby incurring interest expenses that reduce its taxable income. The benefits of borrowing from a foreign parent post-inversion presumably stem from the related party nature of the transaction, and the fewer associated problems stemming from moral hazard and adverse selection.
} 
is untaxed (or taxed very lightly) by the tax haven, and is not taxed by the United States under Subpart F, since the interest recipient is no longer owned by the American company. ${ }^{21}$

\section{Stanley Works: An examination of an expatriation in process}

A close examination of one corporate expatriation offers the opportunity for a detailed analysis of the stock market's reaction. In particular, market value changes can be mapped to projected tax savings arising from sources explored in the previous section. Recent developments surrounding the announced expatriation of Stanley Works have received widespread attention, affording the opportunity to interpret stock market reactions to favorable and unfavorable expatriation events through the lens of tax opportunities. ${ }^{22}$

\subsection{Background and chronology}

Founded in 1843 by Frederick T. Stanley, The Stanley Works ("Stanley”) has grown to nearly 15,000 employees, is part of the Standard \& Poor's 500 Index, and is the leading toolmaker in the United States with sales of $\$ 2.6$ billion by 2001 . Its operations are divided into two groups, Tools (77 percent of sales) and Doors (23 percent of sales). The Tools Group manufactures hand tools for consumer and professional use, mechanics' tools for industrial uses, and pneumatic and hydraulic tools. Hand tools are distributed directly to retail outlets such as home centers and indirectly to end users through third party distributors. Ultimately the products are used for everything from simple around-the-home fix-it jobs to major construction projects ranging from buildings to utilities to railroads. The more sophisticated products find their way onto assembly line equipment at major vehicle makers. The Doors division manufactures a full range of door systems, from ordinary doors for use in residential homes to reinforced commercial systems such as automatic and revolving doors. Door products are sold under a variety of brand names through both direct and indirect sales channels. Much of Stanley's sales are concentrated in a few mass-market home centers - Home Depot, Sears, and Wal-Mart, for example - with Home Depot alone accounting for approximately 18 percent of 2001 revenues.

\footnotetext{
${ }^{21}$ A number of observers, including Avi-Yonah (forthcoming) and the New York State Bar Association Tax Section (2002), suggest that inversions are motivated by desires to reduce U.S. tax liabilities on U.S.-source income via interest stripping. Others, including Thompson (2002) and the United States Department of the Treasury (2002), stress the importance of avoiding U.S. taxation of foreign income.

${ }^{22}$ For a detailed analysis of McDermott's 1983 inversion, see Hines (1991).
} 
On February 8, 2002, Stanley announced its intention to expatriate, and the accompanying press release provided a general outline of its motivation. Stanley would become a Bermuda corporation, which in turn would own the former American parent company. Stanley's foreign operations remain the property of the American company, but would presumably be quickly sold to the Bermuda corporation, thereby removing them from American ownership. The Bermuda corporation would be managed and controlled in Barbados in order to benefit from reduced withholding tax rates provided in the U.S.-Barbados tax treaty.

Chairman and Chief Executive John Trani cited both increased operational flexibility and improved tax efficiency as strategic motivations for implementing the restructuring. Specifically, Trani projected that Stanley's effective income tax rate would fall by 7 to 9 percentage points from its current level of 32 percent. He also clarified that new future foreign entity would continue to be managed out of Stanley's New Britain, CT headquarters and that its then current ownership structure would not change. ${ }^{23}$

Figure 3 provides a price and volume history of Stanley stock trades, along with the movements of the S\&P 500 index from May 1, 2001 to May 20, 2002. The volume movements surrounding the February 8, 2002 announcement indicate that contemporaneous Stanley price changes reflect changes associated with the announced expatriation. On the date of the announcement, the market value of Stanley equity increased by $\$ 199$ million. In the subsequent weeks several developments associated with the operations of Stanley caused substantial movements in the stock price, including a strategic alliance with Home Depot and changed expectations associated with earnings not related to tax obligations. Two expatriation-related

\footnotetext{
${ }^{23}$ The three full quotes attributed to Trani from the press release are: "This strategic initiative will strengthen our company over the long-term. An important portion of our revenues and earnings are derived from outside the United States, where nearly $50 \%$ of our people reside. Moreover, an increasing proportion of our materials are being purchased from global sources. This change will create greater operational flexibility, better position us to manage international cash flows and help us to deal with our complex international tax structure. As a result, our competitiveness, one of the three legs of our vision to become a Great Brand, will be enhanced. The business, regulatory and tax environments in Bermuda are expected to create considerable value for shareowners." "In addition to operational flexibility, improved worldwide cash management and competitive advantages, the new corporate structure will enhance our ability to access international capital markets, which is favorable for organic growth, future strategic alliances and acquisitions. Finally, enhanced flexibility to manage worldwide tax liabilities should reduce our global effective tax rate from its current $32 \%$ to within the range of $23 \%$ - 25\%." "This change has been planned for several months, and the benefits are apparent. The transition should be seamless and transparent for all stakeholders -- employees, customers and vendors -- around the world. Corporate operations will continue to be managed from our current headquarters in New Britain, Connecticut, and these changes will not affect day-to-day operations."
} 
events did cause additional, significant, price movements in the following weeks. The announcement of proposed legislation to limit expatriations on April 11 resulted in a price drop. Finally, on May 10 a shareholder vote on the expatriation passed very narrowly but was challenged by the Connecticut Attorney General, who suggested that "the meeting was rife with voting irregularities." On that day, the market value of Stanley dropped by $\$ 252$ million.

Given the extraordinary volume and dramatic price movements on both February 8, 2002 and May 10, 2002, it is safe to assume that the value changes on those days were associated with changed assessments of future cash flows associated with tax savings stemming from the proposed expatriation. Given that the announcement of the expatriation, as well as the difficulties associated with the shareholder vote, did not involve certain or guaranteed changes in tax savings, it is also safe to assume that the market's evaluation of the aggregate present value of the impact of the expatriation is at least $\$ 250$ million. The actual market assessment of the present value gains associated with expatriation could be considerably higher if these events simply resulted in revised probabilities of realizing those tax savings.

\subsection{Determinants of Stanley's value changes}

What tax savings are embedded in that revision in market value of $\$ 250$ million for Stanley? In particular, what fraction of that present value change can be attributed to savings associated with no longer being subject to U.S. taxation of foreign source income, and what can be attributed to reduced U.S. taxation of domestic source income? Financial details extracted from Stanley's most recent 10-K filing, and presented in Table 2, offer clues to the sources of these dramatic value changes.

As reported in the top panel of Table 2, Stanley's non-U.S. operations, as measured by sales, assets, and pretax earnings, have been declining in absolute terms from 1999 through 2001. Non-U.S. operations contributed 28.2 percent of Stanley's sales, 35.1 percent of its assets, and 10.1 percent of its pretax income in 2001, with the share of assets abroad declining markedly from its 1999 value of 44.7 percent. Current plus deferred foreign income tax provisions, together with reported foreign pretax income, suggest that Stanley faced high average foreign tax rates of approximately 50 percent for the three years from 1999-2001. This interpretation of Stanley's average foreign tax rate is not matched by the reconciliation to the statutory rate presented in the 
middle of Table 2, one that suggests that the average foreign rate was lower than the U.S. statutory rate. $^{24}$ Given this ambiguity, the analysis that follows uses a range of average foreign tax rates to gauge the impact of tax savings associated with foreign source income treatment. The bottom panel of Table 2 provides detail on Stanley's debt and its deferred tax accounts. Interestingly, these notes seem to indicate the possibility of ongoing foreign losses.

Stanley's financial statements and 10-K filings are tools that can be used to manufacture estimates of value changes associated with changes in the treatment of foreign source income - and in particular, the effects of reduced repatriation taxes and greater ability to use domestic interest expenses as tax shields. If Stanley indeed faces a high average foreign tax rate that is expected to persist, then any market value changes should not reflect future savings from reduced repatriation taxes. Given the ambiguity surrounding Stanley's average foreign tax rate, it is possible to determine an upper bound on reduced repatriation taxes subsequent to inversion from an expatriation by assuming that (i) Stanley does not benefit from deferral of U.S. taxes on its foreign income, and (ii) Stanley faces a zero percent average foreign tax rate. These assumptions - which are certainly too strong - imply that reduced repatriation taxes would account for no more than $\$ 83$ million of present and future Stanley benefits from expatriation. ${ }^{25}$

A similar calculation illustrates the tax savings from the ability to receive the full benefits from interest tax shields. If Stanley faces an average interest rate of eight percent on its $\$ 614$ million in debt, then it pays annual interest of \$49 million. If one-third of those interest expenses are allocated to foreign source, and Stanley has excess foreign tax credits so it loses the tax benefits of these deductions, then, at the U.S. statutory rate, an expatriation would create $\$ 57$ million in present value gains from the fact that interest allocation rules would no longer apply. ${ }^{26}$ Implicit in this calculation is the assumption that current debt levels are optimal for these assets.

The benefits of avoiding repatriation taxes and those of avoiding the consequences of interest expense allocation are mutually exclusive, since repatriation taxes arise if a firm has deficit

\footnotetext{
${ }^{24}$ This difference in the implied average foreign tax rates is puzzling and is not found in several other large multinationals we surveyed. It may be possible to reconcile these figures by appealing to different (U.S. and foreign) definitional bases associated with foreign pretax income.

${ }^{25}$ Taking the 2001 level of foreign pretax earnings, assuming these earnings not to grow in the future (which is reasonable given the recent declines), and applying a ten percent discount rate results in a $\$ 83$ million present value gain $[(\$ 23.8$ million $* 35 \%) / 10 \%]$.

${ }^{26}$ This corresponds to the calculation $[(\$ 49 * 33 \% * 35 \%) / 10 \%]=\$ 57$.
} 
foreign tax credits, while interest allocation is expensive only if a firm has excess foreign tax credits. Hence the maximum tax benefit that Stanley can expect to obtain from expatriating is in the $\$ 57-\$ 83$ million range. Even this range is likely to be too high, given the assumptions on which it is based, unless Stanley's foreign income position changes dramatically after inversion. Furthermore, in order to remove Stanley's foreign assets from U.S. ownership, it will be necessary after inversion for the Bermuda parent company to purchase the foreign assets from the American subsidiary, triggering corporate capital gains tax liabilities on any heretofore unrealized capital gains. So the net tax benefits of inverting should be below $\$ 83$ million.

This $\$ 83$ million upper bound estimate falls considerably short of the market value changes on the dates associated with the expatriation - \$252 million in the case of May 10, 2002. Analyst expectations of future Stanley net income reveal similar incongruities that suggest that the value changes experienced by Stanley arise largely from gains other than those associated with the reduced U.S. taxation of foreign income. Salomon Smith Barney, Deutsche Bank, and Merrill Lynch projected increased net income from the expatriation of $\$ 15.3 \mathrm{~m}, \$ 17.1 \mathrm{~m}$ and $\$ 12.8 \mathrm{~m}$ in 2002, respectively, and \$29.8m, \$35.8m, and \$34.1m in 2003, respectively. As illustrated above, such net income improvements are difficult to square with Stanley's historic debt levels and foreign pretax income levels.

Stock market participants evidently consider Stanley's planned expatriation to be considerably more valuable than any reasonable projection of savings from reduced U.S. taxation of foreign source income. This raises at least four possibilities. The first is that these projections are inaccurate; that freedom from U.S. worldwide taxation would open heretofore unrealized opportunities for Stanley that would generate tax savings well beyond anything now projected. This is certainly possible, particularly since removal of U.S. taxation of foreign income changes a firm's incentives to avoid foreign tax obligations. But from the standpoint of projecting future activity, the most reasonable forecast of a firm's future operations are its current operations, and the kind of changes that would have to take place in order to square market valuations with reduced U.S. taxes on foreign income would have to be enormous. ${ }^{27}$ The second possibility is that the stock market is mispricing Stanley stock, which would not be unknown in the annals of Wall

\footnotetext{
${ }^{27}$ Such an interpretation is also difficult to reconcile with the recent decline in the importance of foreign operations to Stanley as measured by geographic segment data presented in Table 2.
} 
Street. The third possibility is that the stock market is reacting to non-tax aspects of the Stanley events, that the $\$ 199$ million stock price jump on the date of announcement reflects the market's favorable evaluation of a company management willing to undertake an inversion, quite apart from their tax benefits, or possibly a more favorable regulatory climate in Bermuda. In this vein, the \$252 million decline following the shareholder vote on May 10, 2002 might include the cost of future difficulties with the State of Connecticut, labor unions, or other stakeholders. While such interpretations are hard to rule out, it is difficult to see why their magnitudes would swamp any tax effects. ${ }^{28}$ And the fourth possibility is that the stock market expects Stanley's expatriation to be associated with significantly reduced domestic tax liabilities on its U.S.-source income. ${ }^{29}$ The fact that the stock market behaves as though something is true does not, of course, make it true, though this behavior often conveys useful information. ${ }^{30}$

\section{Determinants of the decision to expatriate}

This section considers the factors that contribute to the likelihood of expatriation, doing so by analyzing the correlation of measurable firm attributes with whether or not the firm has (as of May 2002) announced plans to invert. The results indicate that inverting firms have features that enhance the potential tax savings available from expatriation, specifically, that inverting firms are large, have sizable foreign assets, extensive debt, and face low foreign tax rates.

The rather small number of inverting firms makes it difficult to analyze their characteristics with techniques commonly applied to large samples of companies. For example, it is infeasible to analyze a random sample of publicly held corporations in the hope of discerning the determinants of foreign inversions, since such a sample will contain only a trivial number of inverting firms. Fortunately, there is an alternative that entails combining information on most inverting firms with information on a sample of firms that do not invert, and analyzing the inversion decision as a logit model. This selection and estimation method yields biased estimates of the constant term of the

\footnotetext{
${ }^{28}$ Investor expectations that reincorporating in Bermuda reduces shareholder control of management should depress share prices following the announcement of plans to invert, leaving an even larger unexplained difference between market reactions and identifiable sources.

${ }^{29}$ Following this logic through to its conclusion suggests that the residual of \$169 million would be associated with a shielding of 23 percent of domestic pretax income from taxes - assuming a flat earnings stream and a 10 percent discount rate - as derived by the following calculation: [( $\$ 169 * 10 \%) / 35 \%) / \$ 212.9]$. The U.S. thin capitalization rules would not prevent such a reduction in the U.S. tax base if Stanley were to attempt it subsequent to inversion.

${ }^{30}$ See Desai (2002) for a related analysis of recent differences between the aggregate book and tax incomes of American corporations, and the extent to which these differences can be attributed to tax sheltering activity.
} 
logit model, which is not of interest in any case, and unbiased estimates of other coefficients, which are of considerable interest.

The data represent a combination of information drawn from the 10-K filings of inverting firms with balance sheet and income statement data from Compustat for other firms, and stock market returns for all companies from CRSP. It is important to select the sample of non-inverting firms on the basis of information other than variables used as regressors, so firms were screened on the basis of continuous provision of export data from 1992 to 1998. Such firms need not have had exports in each year, but must have reported export data for each of those years. All firms reporting such export data in Compustat were included, yielding a sample of 663 firms.

The Compustat data on non-inverting firms contain a number of useful fields, in addition to standard entries such as (book values of) total assets. Geographic segment information is used to identify (book values of) foreign assets, and thereby construct ratios of foreign to total assets. Leverage ratios were constructed as ratios of book values of long-term debt to book values of total assets. $^{31}$ Average foreign tax rates are constructed as ratios of foreign income taxes paid to foreign pretax incomes. In the sample of noninverting companies, this average foreign tax rate in 1997 has a mean of 34.0 percent and a median of 33.2 percent. The foreign tax rate is only available for a limited subsample of noninverting firms, since not all firms distinguish foreign from domestic income and tax payments. As a consequence, the regressions employing foreign tax rates as an explanatory variable have considerably reduced sample sizes. All of the independent variables for the noninverting sample - total assets, foreign asset shares, leverage, and average foreign tax rates - are calculated on the basis of 1997 data.

Table 3 presents estimated coefficients from logit regressions in which the dependent variable equals one if a company undertakes a foreign inversion during the sample period, and equals zero otherwise. The 0.48 coefficient on log assets in the univariate regression reported in column one indicates that firm size significantly affects the propensity to expatriate: larger firms are more likely to do so than are smaller firms. The effect of firm size persists with the introduction of additional independent variables in the regressions reported in columns 2-7. The

\footnotetext{
${ }^{31}$ Compustat provides information on consolidated worldwide debt, which, together with worldwide assets, is used to construct leverage ratios. Since domestic borrowing typically constitutes the majority of a firm's indebtedness, leverage ratios based on worldwide borrowing and assets are excellent proxies for domestic leverage ratios.
} 
ratio of foreign assets to total assets is likewise positively associated with the probability of inverting, as indicated by the 3.68 coefficient in column 2, and similar estimates in columns 5-7. Firms with large ratios of debt to total assets are more likely than others to invert, as indicated by the 3.35 coefficient in column 3 ; this effect is somewhat more pronounced for firms facing high average tax rates, as indicated by the 1.37 coefficient in column 7 . Finally, the estimated effect of average foreign tax rates is negative, meaning that firms whose foreign operations are in low-tax countries are more likely than others to invert, as reflected by the -2.65 coefficient in column 4 . Unfortunately, the noisiness of the average foreign tax rate data, together with the difficulty of obtaining reliable data on average foreign tax rates for large numbers of firms, means that sample sizes are somewhat smaller in these regressions, and the estimated effects of foreign tax rates do not differ significantly from zero.

The regressions reported in Table 3 are consistent with expatriation behavior that is motivated by avoidance of U.S. taxes on foreign income. U.S. taxation of foreign income is burdensome to taxpayers that deploy assets abroad, those that face low tax rates in foreign countries, and those with significant domestic expenses (particularly interest charges) that must be partly allocated against foreign income. One of the interesting features of these results is that they suggest that domestic tax avoidance may not always dominate the decision to expatriate. Firms with greater foreign assets are more likely to invert, which hardly need be the case if the goal is to avoid U.S. taxes on domestic income. Further, if the reduction of domestic tax liabilities were a major motivation for inversions, then one would expect the coefficient on the leverage variable to be negative (instead of its estimated positive value of 3.35). Firms facing high costs of borrowing from unrelated parties, and who therefore have little unrelated-party debt, have the most to gain from the ability to reduce domestic tax liabilities, since they can use excessive borrowing from the new foreign parent company to reduce domestic U.S. tax liabilities. This prediction is complicated by several factors, including the interaction between leverage decisions, tax considerations, and investment opportunities, thereby making it very difficult to use logit analysis to test sharp implications of the hypothesis that expatriation is used as a method of avoiding domestic taxes on U.S.-source income. ${ }^{32}$

\footnotetext{
${ }^{32}$ Tax benefits of inverting are typically related to repatriation patterns, since firms that at low cost defer U.S. taxation of their foreign income have less to gain from expatriating than do those whose foreign income is taxed immediately by the United States. Firms are entitled to report some or all of their foreign income as "permanently reinvested" for
} 


\section{Market reactions to the expatriation decision}

Stock market reactions to announcements that firms plan to expatriate offer useful evidence of revisions in expected future after-tax cash flows associated with the expatriation. The methodology of studying changed asset prices is often used in order to gauge the impact of changed regulatory or tax laws in the finance and accounting literature. In particular, law and economics scholars have used event studies to determine the causes and consequences of domestic reincorporations. $^{33}$

Figure 4 depicts short-term stock market reactions to 19 separate inversion announcements between 1993 and 2002. The figure depicts one-day and five-day differences between returns to holding identified stocks and the returns to holding the S\&P 500 index. ${ }^{34}$ One-day returns represent returns on the trading day that follows the announcement of plans to invert; five-day returns represent cumulative returns that include those on the two days prior to the inversion announcement and the two days that follow. As Figure 4 indicates, stock price reactions were not all positive: only eight of the 19 companies experienced positive abnormal returns over the one-day window, and only ten did so over the five-day window. Since larger firms tended to exhibit positive price reactions to inversions, average abnormal returns to inversion announcements, weighted by market capitalization, were positive: 0.3 percent over the one-day window, and 1.7 percent over the five-day window. Clearly, the stock market is concerned in many cases either that the costs of inverting exceed the benefits under current law, or that future tax or regulatory changes might reduce the benefits of inverting.

It is instructive to consider the extent to which observable factors are correlated with stock price reactions to inversion announcements. Given the tax environment in which American firms

accounting purposes, thereby removing the requirement that anticipated future repatriation taxes be currently included in deferred taxes and thereby reduce book income. The degree of disclosure varies greatly between firms, although a number of inverting firms in the sample, notably Stanley and Noble Drilling, indicate that they have substantial amounts of permanently reinvested foreign earnings. Subsequent repatriations by these firms would trigger accounting as well as tax costs, both of which would be avoided by successfully inverting.

${ }^{33}$ For example, see Romano (1985) and the literature summarized in Daines (2001) regarding the primacy of Delaware as a corporate incorporation base.

${ }^{34}$ It is necessary to measure excess returns because companies invert on different days, during some of which the stock market as a whole did well, while during others the market fell. Stock returns equal percent changes in end-of-day share prices. These represent total returns on event days, since none of the 19 inverting companies in the sample paid dividends during these event windows. Returns to holding the S\&P 500 index consist of dividends plus share price movements. 
operate, there are some factors, such as low foreign tax rates and high leverage ratios, that are expected to contribute to the benefits of undertaking inversions. These factors cannot be measured perfectly with the available data, though they can be approximated. The costs of inversions include not only the administrative costs of undertaking inversion transactions, but also the capital gains tax liabilities that they entail. As discussed in section 3.2, the nature and magnitude of the capital gains tax liability at the time of expatriation depends on the form in which an inversion is executed.

Since taxable stock transfers are the most common type of inversion transaction, we use a measure of shareholder basis in order to evaluate the capital gains tax cost of undertaking inversions. ${ }^{35}$ Unfortunately, there is no direct information available on shareholder basis. Instead, we take weighted averages of one- and two-year stock price histories (prior to inversion announcements) as rough proxies for stock purchase prices of individual shareholders. In these calculations, daily stock transaction volumes are used as weights, which are constrained to sum to one for each stock. While transaction volumes of the stock of inverting companies in the year prior to inversion announcements typically exceed the total outstanding interest in the stock, it does not follow that one-year prices offer exact measures of shareholder basis. Taxable shareholders with significant long-term unrealized capital gains are the least likely to sell their shares, so sales in any given year are likely to be dominated by shares held by tax exempt entities or those without large positive gains. Hence these weighted stock prices are only rough proxies for the actual basis of taxable shareholders. ${ }^{36}$

Figure 5 depicts ratios of stock prices at times of inversion announcements to average prices in the preceding one- and two-year intervals. Despite a generally rising stock market during the 1990s, only four of the firms in the sample rose in value over the year prior to announcing plans to invert. The median ratio of market price at the time of inversion to one-year historic

\footnotetext{
${ }^{35}$ Firms can choose among several inversion methods, not all of which entail recognition of capital gains by taxable shareholders. While a few of the inverting firms in our sample use methods that do not trigger such capital gains taxes, it is nevertheless appropriate to measure the cost of inverting by the taxes that would have been incurred if taxable stock transfers had been used. A taxable stock transfer is the primary inversion method used by American corporations, others being chosen presumably whenever less expensive. Since it is not possible to obtain direct data on the tax costs of other inversion methods, we use instead the closest proxy, which is the cost of a taxable stock transfer. ${ }^{36}$ Data on shareholder basis are generally unavailable to researchers; for an exception, see the study of the RJR Nabisco leveraged buyout by Landsman and Shackelford (1995). Market transaction approaches to estimating basis, of the type used in this paper, are considerably more common; for a recent example, see Grinblatt and Han (2002).
} 
purchase price is 88.4 percent, and the median ratio of market price to two-year historic purchase price is 84.2 percent. The fact that expatriating firms tend to be those with falling stock prices suggests that the associated capital gains liabilities influence the inversion decision, though it is possible to subject this hypothesis to a sharper test.

Assuming that the stock market prices shares rationally, then the basis of existing shareholders should not directly influence price reactions to inversion announcements, since postinversion stock prices are determined by expected future returns. Once an inversion is complete, taxpayers recognize their capital gains or losses, and, from the standpoint of the stock market, the basis that shareholders once had is irrelevant to valuations. Consequently, price reactions to inversion announcements should indicate simply what the stock market believes to be the benefits of changing corporate residence from the United States to a new offshore home. ${ }^{37}$ Shareholder basis is likely to affect price performance at inversion announcement only as a reflection of the decision rules that managements use in choosing whether or not to have their companies expatriate. If corporate management maximizes the wealth of shareholders, rather than share price, then management will undertake inversions only if the expected benefits exceed anticipated costs, including the cost of capital gains realizations. Hence this decision rule implies that very low shareholder basis in an inverting company should be accompanied by considerable tax benefits as reflected in higher share prices.

Figure 6 offers a scatter plot of data on the nineteen sample companies, in which the horizontal axis is the ratio of stock price at time of inversion to the average price in the preceding year, and the vertical axis is the excess stock return on the day of the inversion announcement. As the figure shows, there is a strong positive relationship between the potential capital gains tax liability (so measured) and price reactions. The upward sloping solid line in Figure 6 that captures this relationship is estimated by a univariate OLS regression that is presented in the first column of Table 4. The estimated regression coefficient indicates that a 10 percent larger capital gain is associated with 1.1 percent higher price reaction upon announcement of plans to invert.

\footnotetext{
${ }^{37}$ Note that it is possible that share prices prior to inversions are elevated by shareholder reluctance to sell stocks in which they have considerable unrealized capital gains. This behavior would therefore depress the inversion price reactions of firms whose shareholders have low basis, and therefore mitigate against the findings depicted in Figure 6 and reported in Table 4.
} 
The positive correlation of share price appreciation in the year prior to inversion and that on the day the inversion announcement is made public is consistent with rational tax planning on the part of inverting firms and managers maximizing shareholder wealth rather than share prices. A taxable investor facing a 20 percent capital gains tax rate incurs a cost, at time of realization, of two percent of firm value for every ten percent of historic price appreciation. Such an investor would require that an inversion transaction generate future tax savings of at least 2.5 percent of firm value, for each 10 percent of historic appreciation, in order to warrant incurring current capital gains tax liabilities. ${ }^{38}$ Of course, not all shareholders are taxable, not all are taxed at 20 percent on their capital gains, and even among taxable shareholders, many will ultimately incur capital gains liabilities on their share appreciation whether or not the company inverts. So required returns should be somewhat less than 2.5 percent for every 10 percent of price appreciation, and the estimated value of 1.1 percent is quite a reasonable figure for companies to use.

Figure 7 presents scatter plots of price reactions and other observable characteristics of inverting companies. The absence of complete reporting by companies in the sample makes it impossible to include all inverting firms in these scatters, and the noisiness of the available information for firms that do report makes inferences difficult to draw with such small samples. Nevertheless, it is useful to consider this evidence. The top two scatters depicted in Figure 7 indicate that there is no discernible relationship between foreign asset shares, or foreign tax rates, and price reactions to inversion announcements. The bottom two scatters indicate that foreign income shares are mildly correlated with price reactions, while firm leverage is much more strongly correlated. Share prices of firms with high (book) ratios of debt to total assets rise abnormally in response to inversion announcements. The univariate regression reported in column two of Table 4 indicates that share prices of firms with ten percent higher (book) ratios of debt to total assets rise by 0.7 percent more on the announcement of plans to invert.

The correlation of leverage ratios and share price reactions is again consistent with careful tax planning on the part of inverting firms. Taking a firm's return on assets to be roughly equal to its borrowing rate, increasing the firm's leverage ratio by ten percent generates interest deductions

\footnotetext{
${ }^{38}$ Letting $\tau_{c}$ denote the capital gains tax rate, and $g$ denote the share price change upon expatriation, the break-even condition is that $1=\left(1-\tau_{c}\right)(1+g)$, which in turn implies that $g=\frac{\tau_{c}}{\left(1-\tau_{c}\right)}$.
} 
equal to ten percent of firm value, or 3.5 percent after tax (for a firm facing the U.S. corporate tax rate of 35 percent). If inverting firms have excess foreign tax credits with 60 percent probability, ${ }^{39}$ and roughly one third of their assets (now and in the future) are located abroad, then the expected cost of interest expense allocation under U.S. tax rules is simply $(3.5)(0.6) / 3=0.7$ percent of firm value for each additional ten percent of leverage. That price responses to inversion announcements closely match their predicted values offers evidence that markets accurately assess the value of expatriating.

\section{Conclusion}

American multinational companies are reincorporating as foreign companies at an accelerating rate. This development is clearly a reaction to the incentives created by the U.S. system of taxing worldwide income, as it contrasts with foreign tax systems. The evidence in the paper suggests that the decision making calculus associated with expatriation is not limited to the desire to avoid taxes on the repatriation of income associated with U.S. tax rules. Instead, allocation rules associated with lost tax shields from interest expense, domestic earnings stripping possibilities, and the forced realizations of capital gains for shareholders are all operative in the minds of managers contemplating, and shareholders reacting to, expatriations.

The analysis of the reaction to Stanley Works' expatriation provides some evidence that revised expectations of future cash flows associated with gains from the avoidance of repatriation taxes and the better ability to utilize fully interest tax shields cannot account fully for changed valuations. This analysis raises the intriguing possibility that managers and shareholders allowed for the possibility of reductions in domestic tax obligations in their consideration of the expatriation. This inference is based on a number of strong assumptions associated with interpreting accounting statements but, presumably, those were the same statements that investors used in valuing the expatriation.

While there is not yet a large enough sample of expatriating companies to draw statistically compelling generalizations, some aspects of the decision to invert are clear. Large firms are the most likely to invert, as are those with significant fractions of their assets located

\footnotetext{
${ }^{39}$ See Grubert, Randolph, and Rousslang (1996) for evidence on the foreign tax credit status of large American multinational firms.
} 
abroad. Heavily leveraged firms are more likely to invert than are other firms, as are firms facing low tax rates in the foreign countries in which they operate. All of these patterns are consistent with incentives created by the U.S. system of taxing worldwide income, and notably, reflect the importance of expense allocation rules and fixed costs of tax planning associated with inversions.

Stock price movements provide evidence that is consistent with these determinants of the inversion decision. Among inverting companies, share price reactions to inversion announcements are positively correlated with potential shareholder capital gains tax liabilities, suggesting that managers incorporate the capital gains burdens inversions impose on shareholders. Finally, the prices of highly leveraged firms react to inversion announcements more positively than do the prices of other firms, which reflects the benefits of avoiding the U.S. regime of allocating interest expenses between domestic and foreign source for tax purposes. The fact that embedded shareholder capital gains discourage inversions suggests a natural counterweight to the rush to expatriate, one that supplements any costs associated with being subject to the corporate laws of new host countries, and the public relations impact of abandoning the United States. This evidence is consistent with managers maximizing shareholder wealth rather than share prices, and therefore more readily expatriating if their firms have relatively poor recent stock price performance.

This paper concerns expatriations by American companies, which is a recent vignette in the much larger drama of multinational businesses and the U.S. tax system. The same tax provisions that encourage American companies to reincorporate abroad also encourage foreign firms to acquire American firms, encourage entrepreneurs to establish their companies initially in foreign countries, encourage American companies to engage in unproductive tax avoidance, and may, over time, simply diminish the after-tax profitabilities of firms that elect to remain American and pay their taxes. Corporate expatriation is simply a very visible symbol of the impact of a U.S. tax system that significantly influences the behavior of multinational firms and that differs from what is available elsewhere in the world. 


\section{References}

Atlshuler, Rosanne, T. Scott Newlon and William C. Randolph, Do repatriation taxes matter? Evidence from the tax returns of U.S. multinationals, in Martin Feldstein, James R. Hines Jr., and R. Glenn Hubbard eds., The Effects of Taxation on Multinational Corporations (Chicago: University of Chicago Press, 1995), 253-272.

Avi-Yonah, For haven's sake: Reflections on inversion transactions, Tax Notes (forthcoming).

Collins, Julie H. and Douglas A. Shackelford, Corporate domicile and average effective tax rates: The cases of Canada, Japan, the United Kingdom, and the United States, International Tax and Public Finance, May 1995, 2 (1), 55-83.

Daines, Robert. Does Delaware law improve firm value? Journal of Financial Economics, December 2001, 62 (3), 525-558.

Desai, Mihir A., The corporate profit base, tax sheltering activity, and the changing nature of employee compensation, NBER Working Paper No. 8866, March 2002.

Desai, Mihir A. and James R. Hines Jr., "Basket" cases: Tax incentives and international joint venture participation by American multinational firms, Journal of Public Economics, March 1999, 71 (3), 379-402.

Desai, Mihir A., C. Fritz Foley and James R. Hines Jr., Repatriation Taxes and Dividend Distortions National Tax Journal, December 2001, 54 (4), 829-851.

Desai, Mihir A., C. Fritz Foley and James R. Hines Jr., Chains of Ownership, Tax Competition, and Foreign Direct Investment, Working Paper, Harvard University, 2002.

Froot, Kenneth A. and James R. Hines Jr., Interest allocation rules, financing patterns, and the operations of U.S. Multinationals, in Martin Feldstein, James R. Hines Jr., and R. Glenn Hubbard eds., Taxing multinational corporations (Chicago: University of Chicago Press, 1995), 277-307.

Gordon, Roger H. Can capital income taxes survive in open economies? Journal of Finance, July 1992, 47 (3), 1159-1180.

Gordon, Roger H. and James R. Hines Jr., International taxation, in Alan J. Auerbach and Martin Feldstein eds., Handbook of Public Economics, Volume 4 (Amsterdam: Elsevier, forthcoming).

Grinblatt, Mark and Bing Han, The disposition effect and momentum, NBER Working Paper No. 8734, January 2002.

Grubert, Harry, Taxes and the division of foreign operating income among royalties, interest, dividends and retained earnings, Journal of Public Economics, May 1998, 68 (2), 269-290. 
Grubert, Harry, Tax planning by companies and tax competition by governments, in James R. Hines Jr. ed., International Taxation and Multinational Activity (Chicago: University of Chicago Press, 2001), 113-139.

Grubert, Harry, William C. Randolph and Donald J. Rousslang, Country and multinational company responses to the Tax Reform Act of 1986, National Tax Journal, September 1996, 49 (3), 341-158.

Hines, James R., Jr., The flight paths of migratory corporations, Journal of Accounting, Auditing, and Finance, Fall 1991, 6 (4), 447-479.

Hines, James R., Jr. On the sensitivity of R\&D to delicate tax changes: The behavior of U.S. multinationals in the 1980s, in Alberto Giovannini, R. Glenn Hubbard and Joel Slemrod eds., Studies in International Taxation (Chicago: University of Chicago Press, 1993), 149-187.

Hines, James R., Jr., Credit and deferral as international investment incentives, Journal of Public Economics, October 1994, 55 (2), 323-347.

Hines, James R., Jr., Altered states: Taxes and the location of foreign direct investment in America, American Economic Review, December 1996, 86 (5), 1076-1094.

Hines, James R., Jr., Tax policy and the activities of multinational corporations, in Alan J. Auerbach ed., Fiscal Policy : Lessons from Economic Research (Cambridge, MA : MIT Press, 1997), 401-445.

Hines, James R., Jr., Lessons from behavioral responses to international taxation, National Tax Journal, June 1999, 52 (2), 305-322.

Hines, James R., Jr., “Tax sparing” and direct investment in developing countries, in James R. Hines Jr. ed., International Taxation and Multinational Activity (Chicago: University of Chicago Press, 2001), 39-66.

Hines, James R., Jr. and R. Glenn Hubbard, Coming home to America: Dividend repatriations by U.S. multinationals, in Assaf Razin and Joel Slemrod eds., Taxation in the Global Economy (Chicago: University of Chicago Press, 1990), 161-200.

Hines, James R., Jr. and R. Glenn Hubbard, Appendix, in: Martin Feldstein, James R. Hines Jr., and R. Glenn Hubbard eds., Taxing multinational corporations (Chicago: University of Chicago Press, 1995), 103-106.

Hufbauer, Gary C., U.S. taxation of international income: Blueprint for reform (Washington D.C.: Institute for International Economics, 1992).

Kramer, J.L. and G.C. Hufbauer, Higher U.S. taxation could prompt changes in multinational corporate structure, International Tax Journal, Summer 1975, 1 (4), 301-324. 
Landsman, Wayne R. and Douglas A. Shackelford, The lock-in effect of capital gains taxes: Evidence from the RJR Nabisco leveraged buyout, National Tax Journal, June 1995, 48 (2), 245 259.

New York State Bar Association Tax Section, Report on outbound inversion transactions, May 2002.

Reich, Robert B., Who is us? Harvard Business Review, January/February 1990, 68 (1), 53-64.

Romano, Roberta. Law as a product: Some pieces of the incorporation puzzle. Journal of Law, Economics and Organization, Fall 1985, 1 (2), 225-283.

Thompson, Samuel C., Jr., Section 367: A 'wimp' for inversions and a 'bully' for real crossborder acquisitions, Tax Notes, March 18, 2002, 94 (11), 1505-1548.

United States Department of the Treasury, Office of Tax Policy, Corporate inversion transactions: Tax policy implications, May 2002. 


\section{Figure 1:}

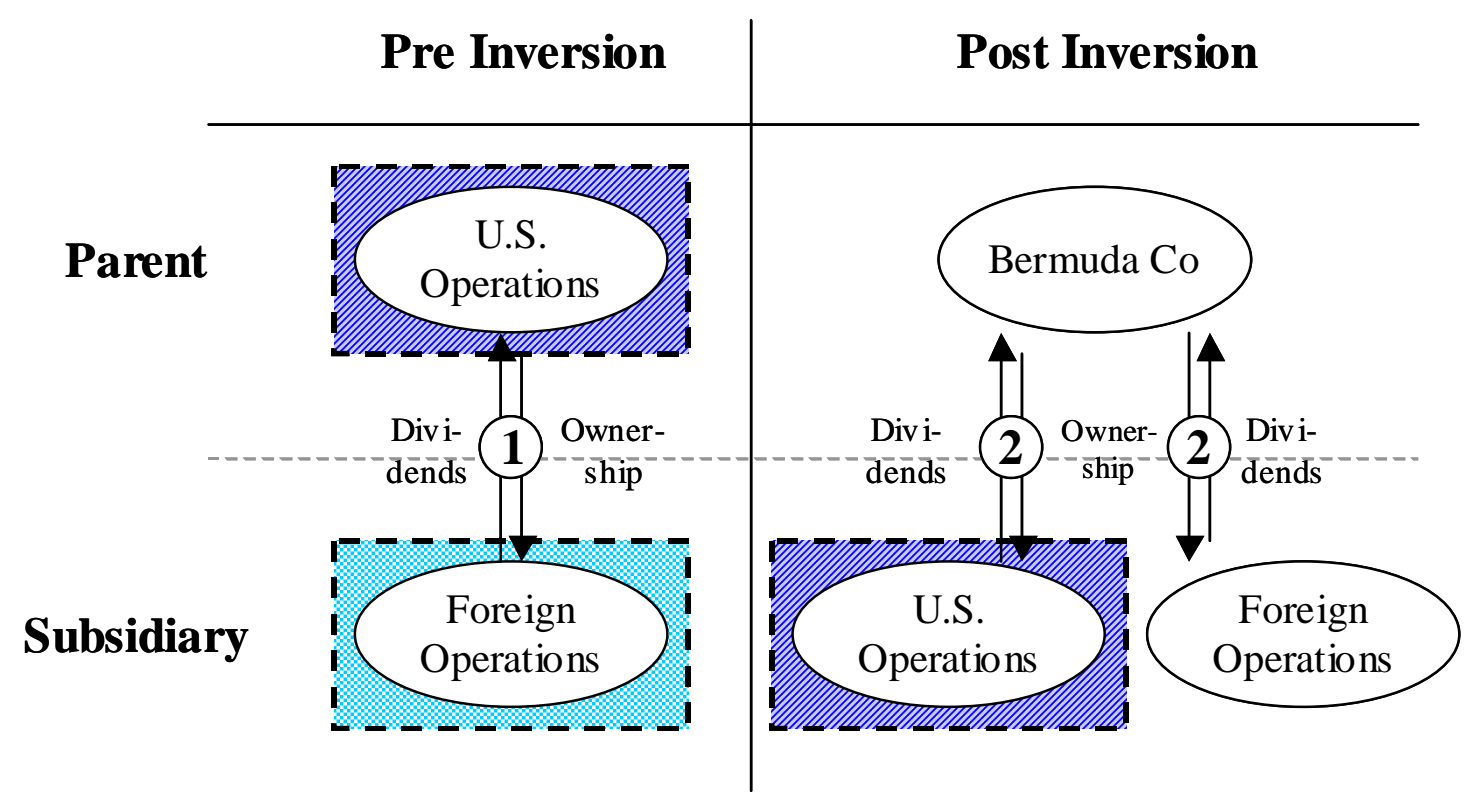

\section{Transaction Summary}

(1) U.S. parent owns all world wide operations

(2) Bermuda parent owns U.S. and foreign operations separately

Subject to full U.S. taxation

1. Subject to adjusted U.S. taxation 1. (repatriations, foreign tax credits)

Note: Foreign operations owned by a U.S. parent company before the inversion are subject to U.S. worldwide taxation. If foreign operations are transfered to the Bermuda parent company in the inversion, those operations will no longer produce income taxable by the United States. 
Figure 2:

Expatriation Methods

Stock Inversion

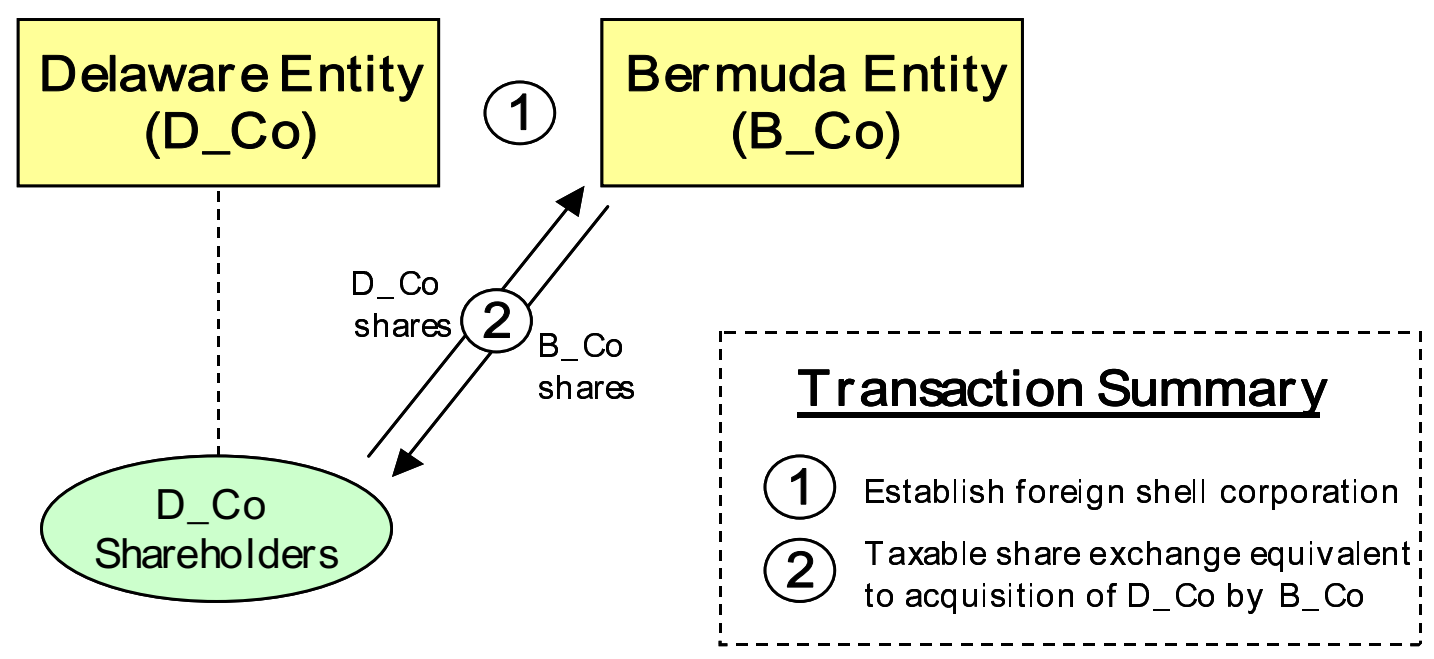

Asset Inversion

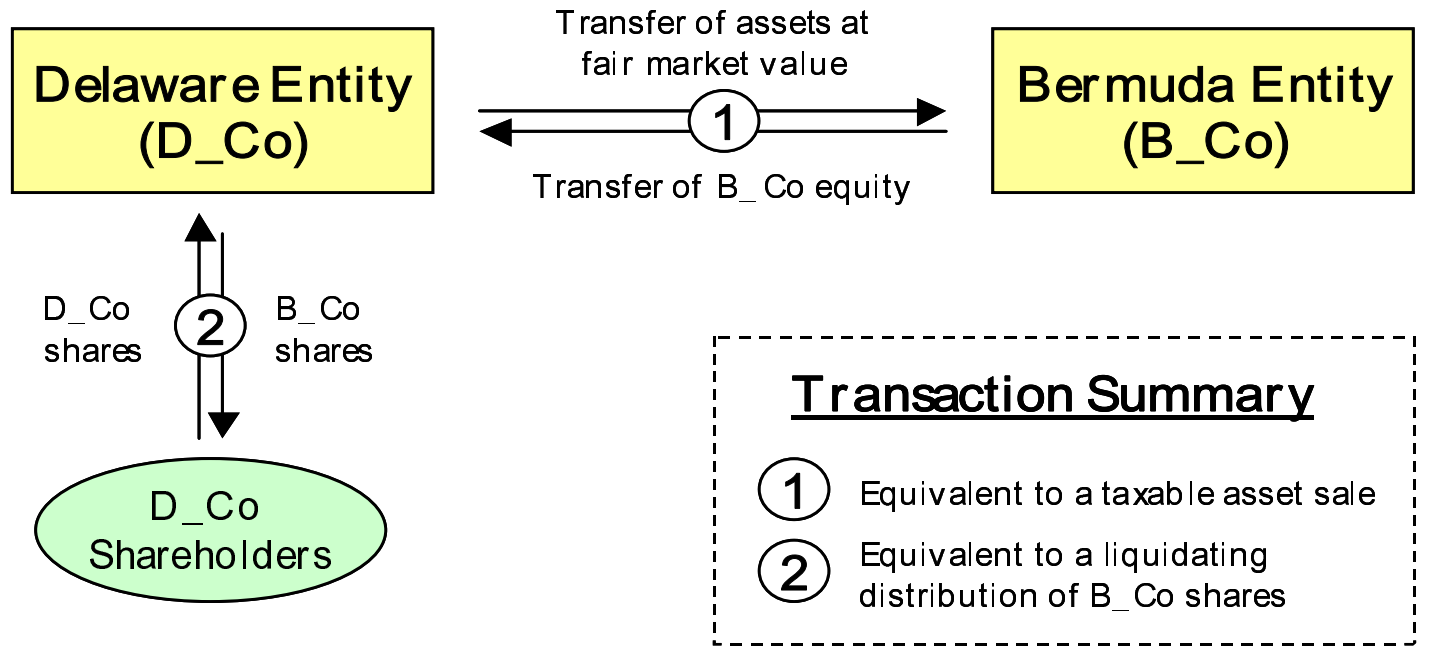

Note: In a stock inversion, U.S. shareholders execute a taxable share exchange, trading their old shares in the U.S. entity for shares in the newly created foreign entity. In an asset inversion, all of the assets of the U.S. entity are transferred to the foreign entity (which has no material assets) in exchange for stock in the foreign entity, and a taxable gain is realized on the excess of fair market value over the U.S. entity's cost basis in those assets. The U.S. entity is then liquidated and the foreign entity shares are distributed to the public shareholders. 


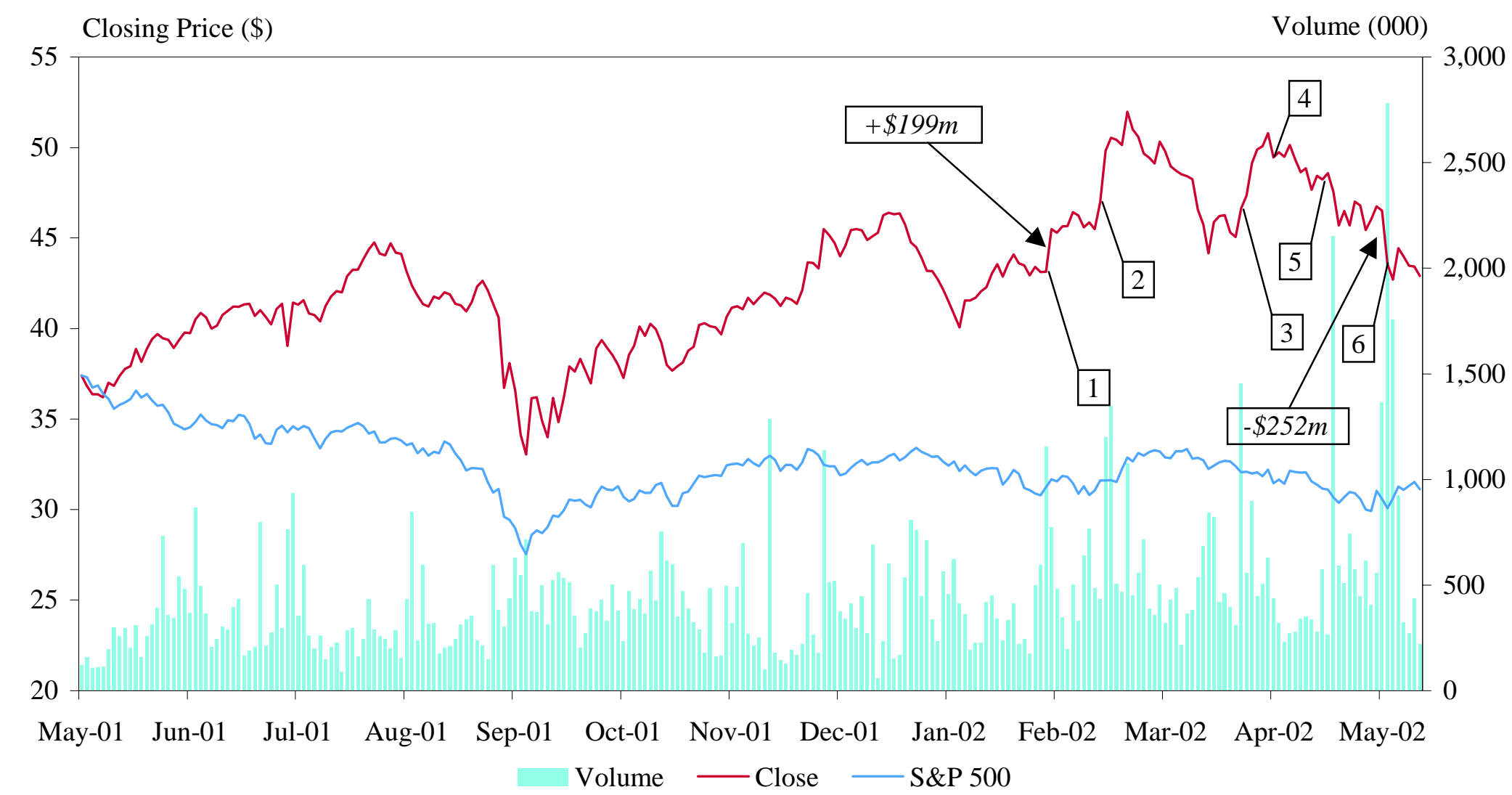

1 Announces intention to execute inversion transaction to Bermuda
Announces strategic alliance with Home Depot

Increases analyst guidance figures based on strong retail sales; this and all other earnings estimates exclude the possible impact of reincorporation in Bermuda

\begin{tabular}{|c|c|}
\hline 4 & 4/11/02 \\
\hline 5 & $4 / 26 / 02$ \\
\hline 6 & $5 / 10 / 02$ \\
\hline
\end{tabular}

Senate to draft legislation eliminating and reversing inversion transactions

First quarter earnings rose due to cost cutting measures; results reflected "continuing weak markets"

Stanley Works agrees to hold a revote by shareholders after the initial vote only approved the inversion transaction by a very narrow margin above the required two thirds majority and the Connecticut Attorney General declared the meeting "rife with voting irregularities"

Note: The dark line in the figure depicts daily closing stock prices for Stanley Works on trading days between May 21, 2001 and May 20, 2002, measured on the left axis. The light line depicts closing values of the S\&P 500 index, normalized by Stanley's closing price on May 21, 2001. The lightly shaded bars measure daily volumes of Stanley stock trades, measured on the right axis as thousands of shares.

Source: Authors' calculations from data reported by CRSP and Compustat. 
Figure 4:

Excess Returns to Corporate Expatriation Announcements
$(15 \%)$
$(10 \%)$
$(5 \%)$
$5 \%$
$10 \%$
$15 \%$

Helen Of Troy (1993)

Triton Energy (1996)

Tyco (1997)

Fruit Of The Loom (1998)

Xoma (1998)

Gold Reserve (1998)

Transocean (1999)

PXRE (1999)

Everest Reinsurance (1999)

White Mountain Insurance (1999)

Trenwick (1999)

R\&B Falcon (2000)

Foster Wheeler (2000)

Cooper Industries (2001)

Global Marine (2001)

Ingersoll Rand (2001)

Nabors Industries (2002)

Noble Drilling (2002)

Stanley Tools (2002)
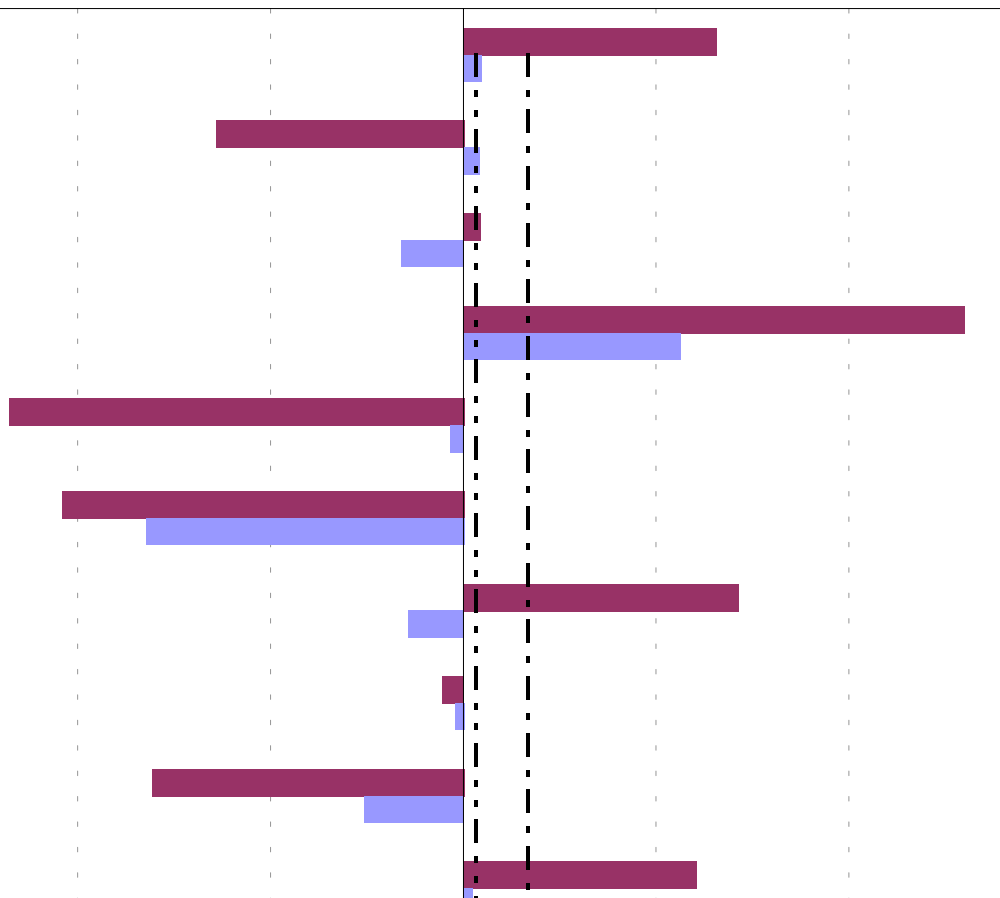

5 Day

1 Day - - - Weighted Mean (5 Day) - - - Weighted Mean (1 Day)

Note: Bars in the figure depict differences between returns to inverting firms and S\&P 500 index returns at the times inversions are announced. Darkly shaded bars depict return differences over five-day windows centered on inversion announcements; lightly shaded bars depict return differences on announcement days.

Source: Authors' calculations from data reported by CRSP, Dow Jones Newswire, and SEC Documents. 
Figure 5:

Ratio of Stock Prices at Inversion Announcement to Prices in Preceding Years

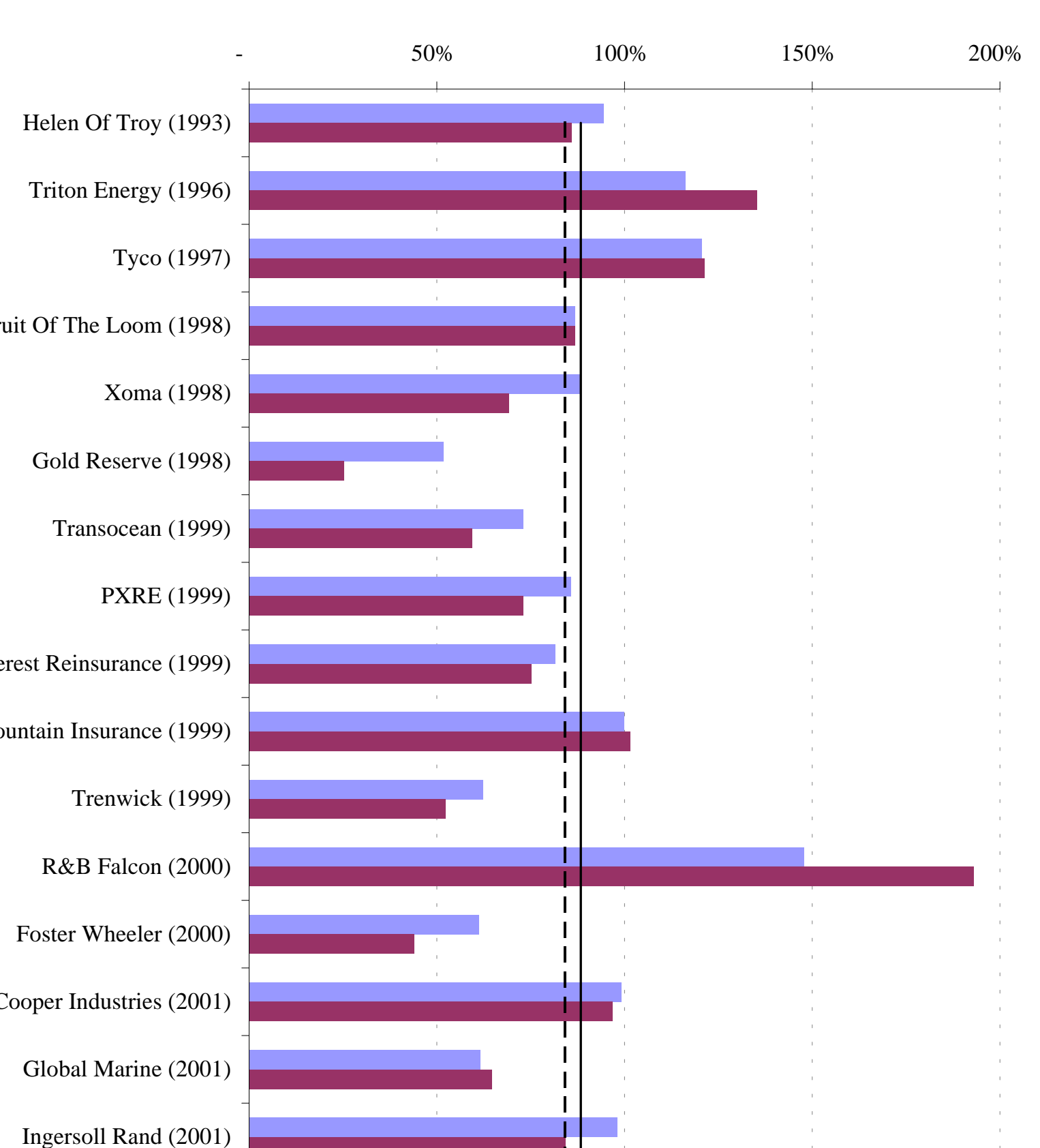

Xoma (1998)

Gold Reserve (1998)

Transocean (1999)

PXRE (1999)

Everest Reinsurance (1999)

White Mountain Insurance (1999)
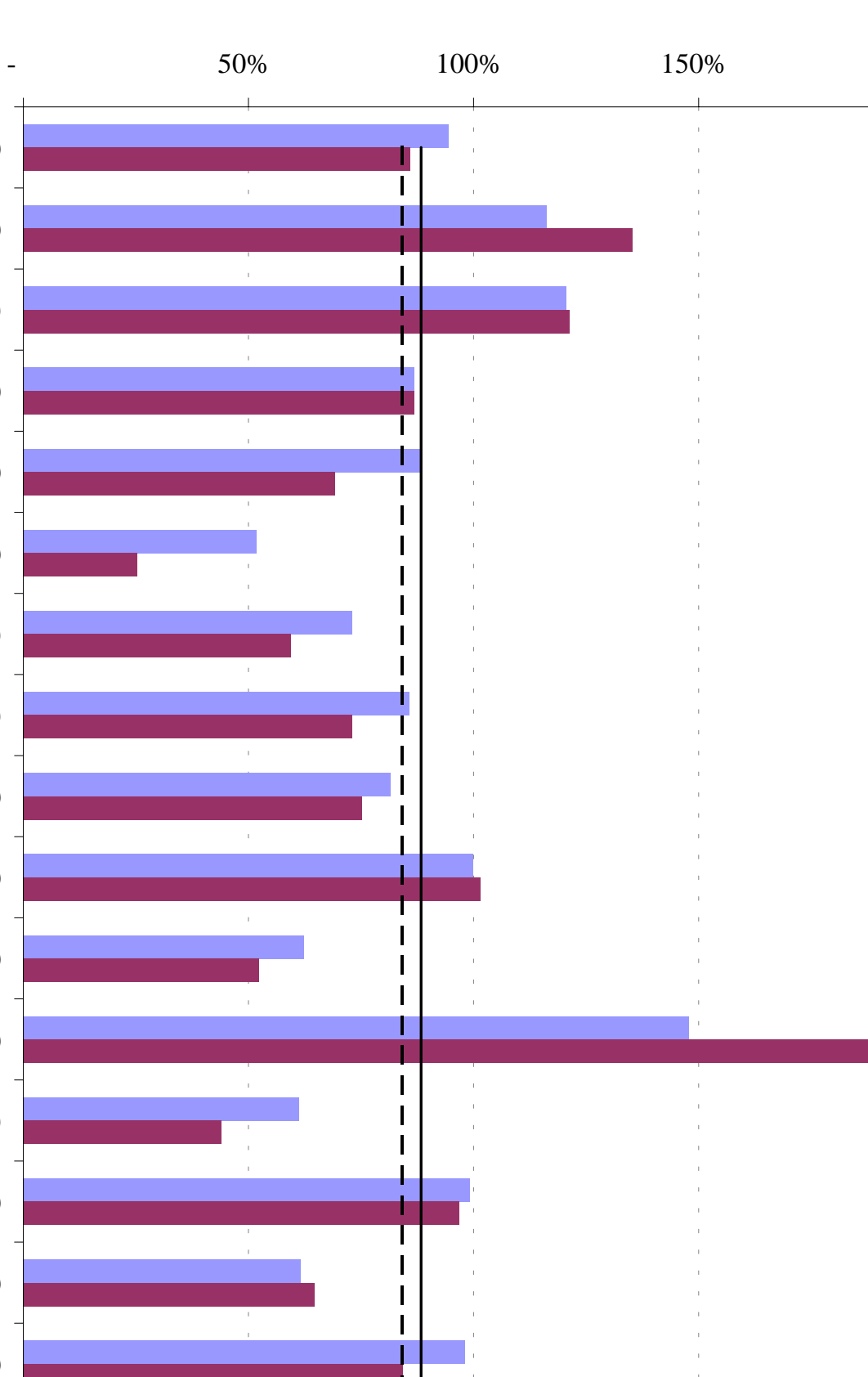

Fruit Of The Loom (1998)
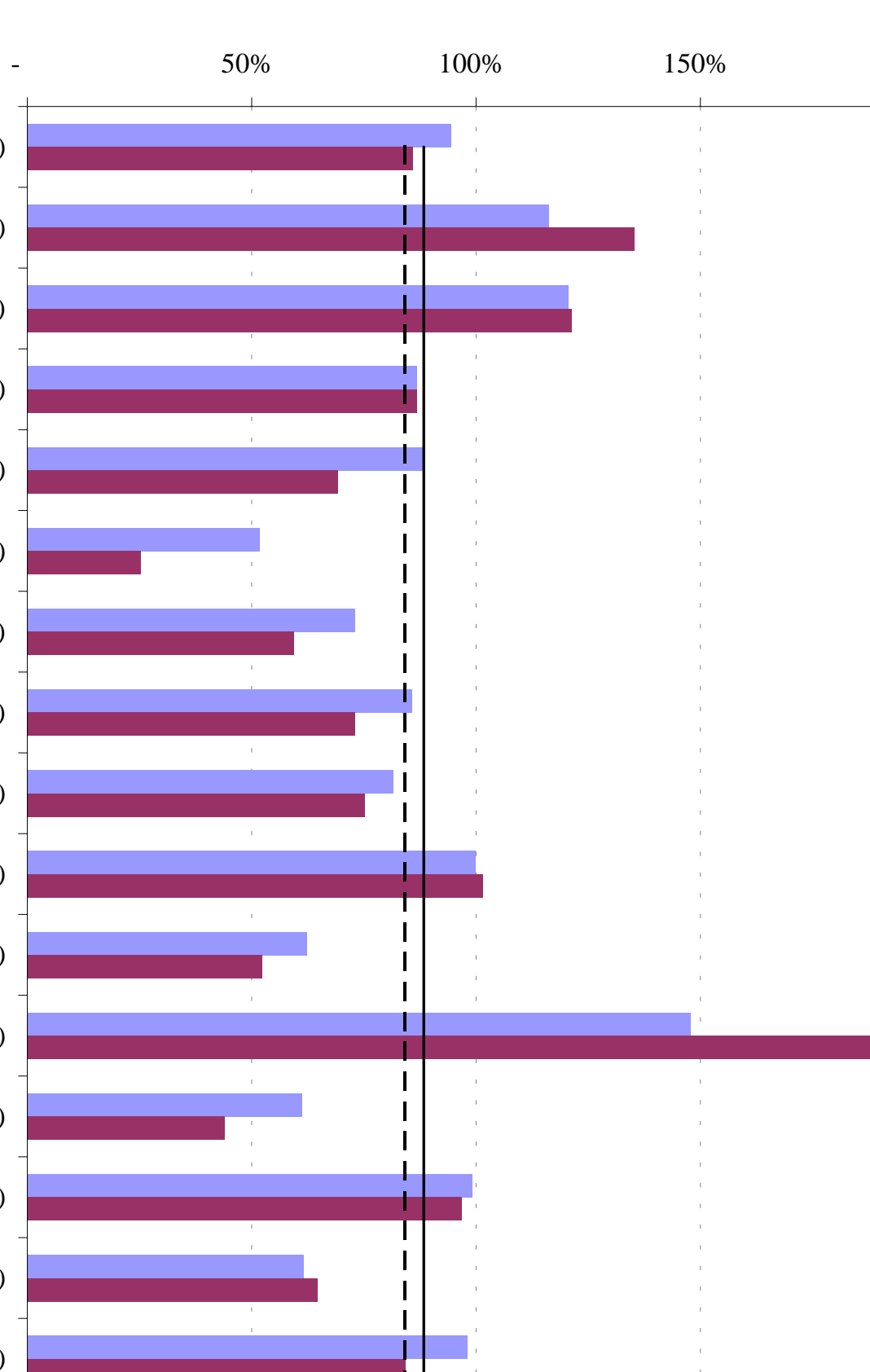

Trenwick (1999)

R\&B Falcon (2000)

Foster Wheeler (2000)

Cooper Industries (2001)

Global Marine (2001)

Ingersoll Rand (2001)

Nabors Industries (2002)

Noble Drilling (2002)

Stanley Tools (2002)
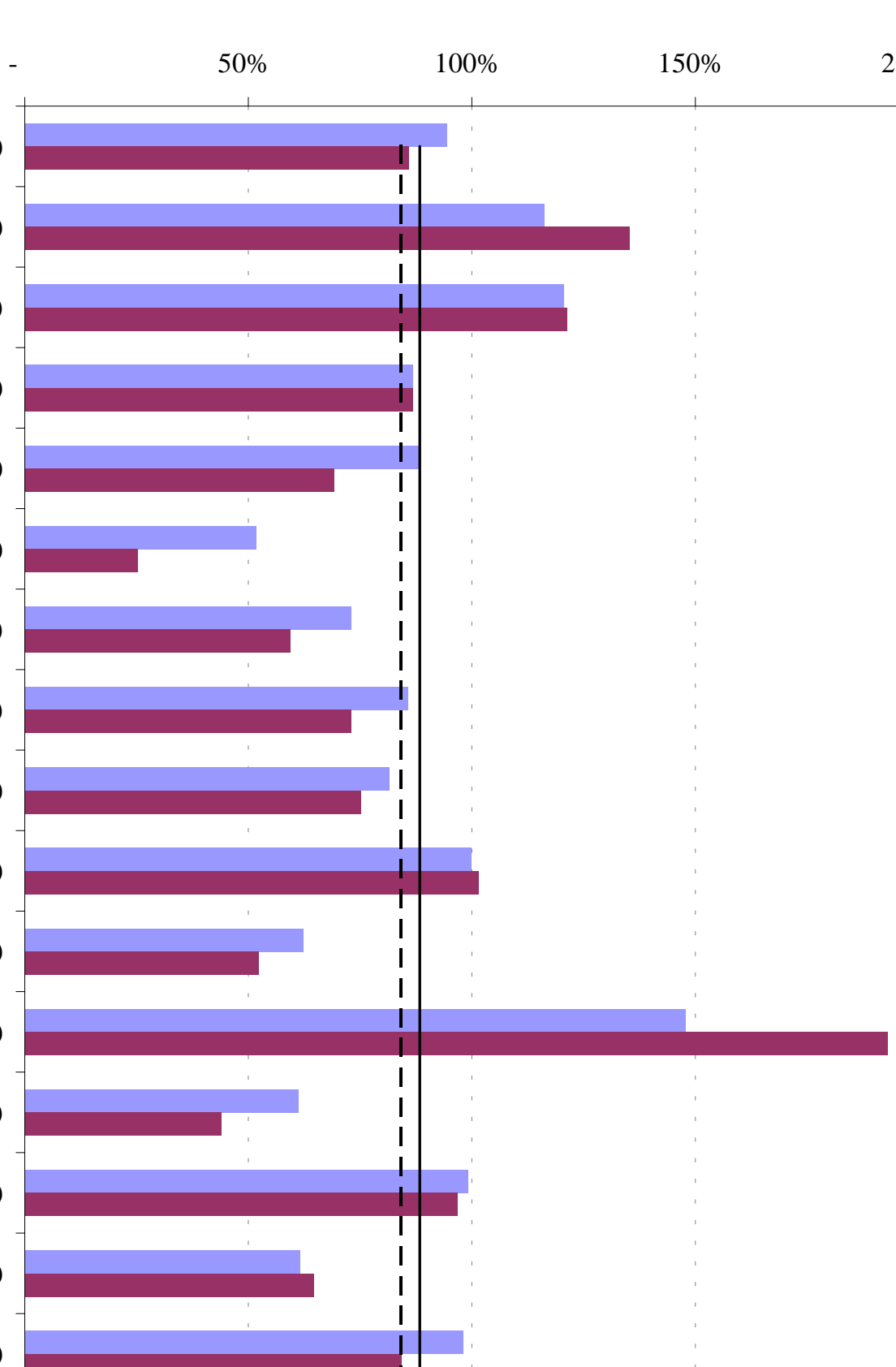

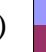
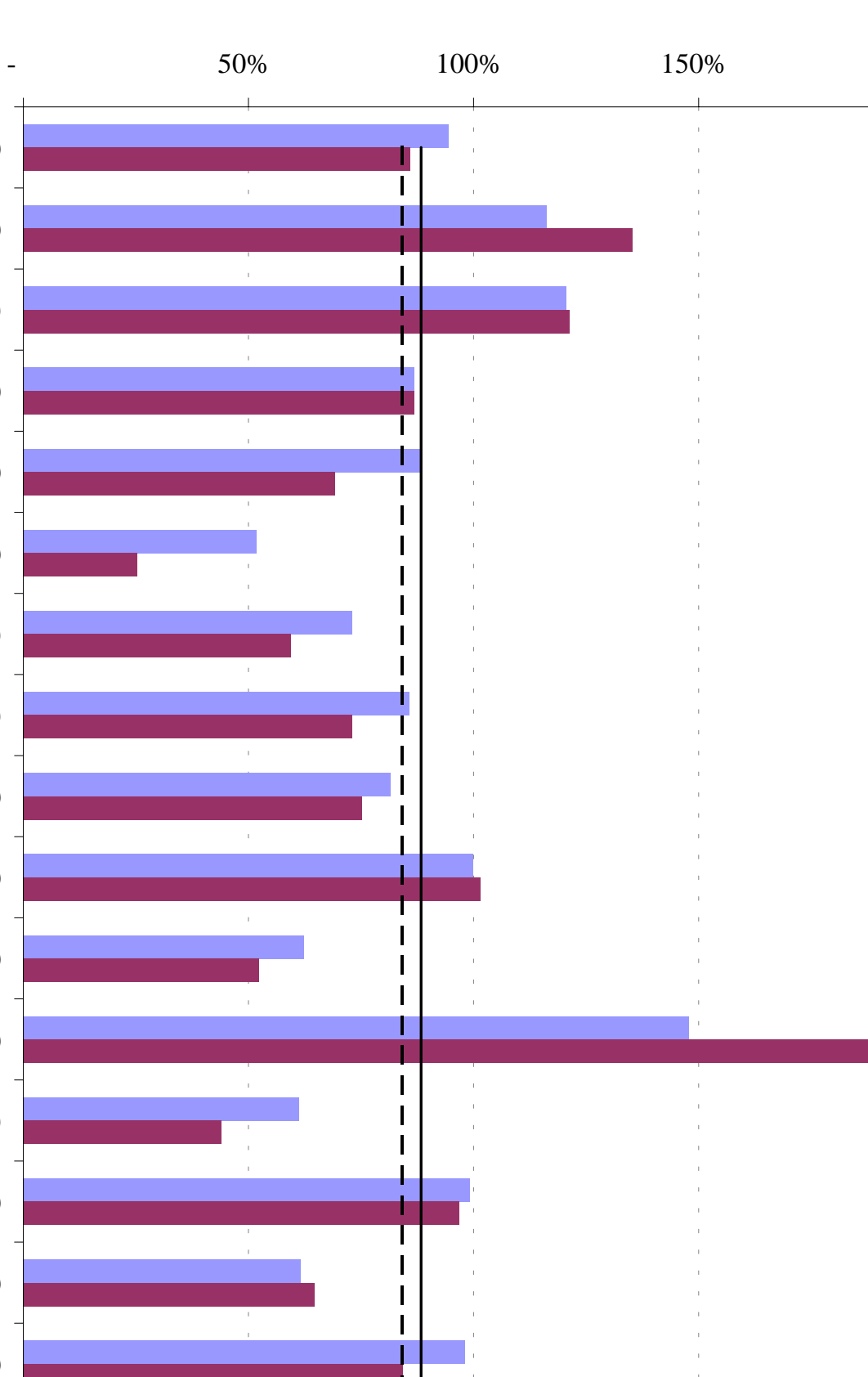

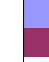

)

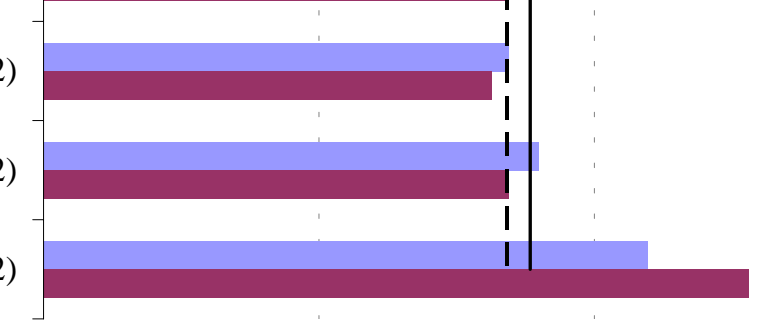

\section{Prior Year}

Median (1 Yr)

Prior Two Years

$$
\text { - - Median (2 Yrs) }
$$

Note: The figure depicts ratios of closing stock prices on the days prior to inversion announcements to average closing stock prices for the preceding year and two years. One-year and two-year prior stock prices are daily averages weighted by daily trading volumes.

Source: Authors' calculations from data reported by CRSP, Dow Jones Newswire, and SEC Documents. 


\section{Figure 6:}

\section{The Relationship between Excess Returns to Expatriations and}

Shareholder Embedded Gains

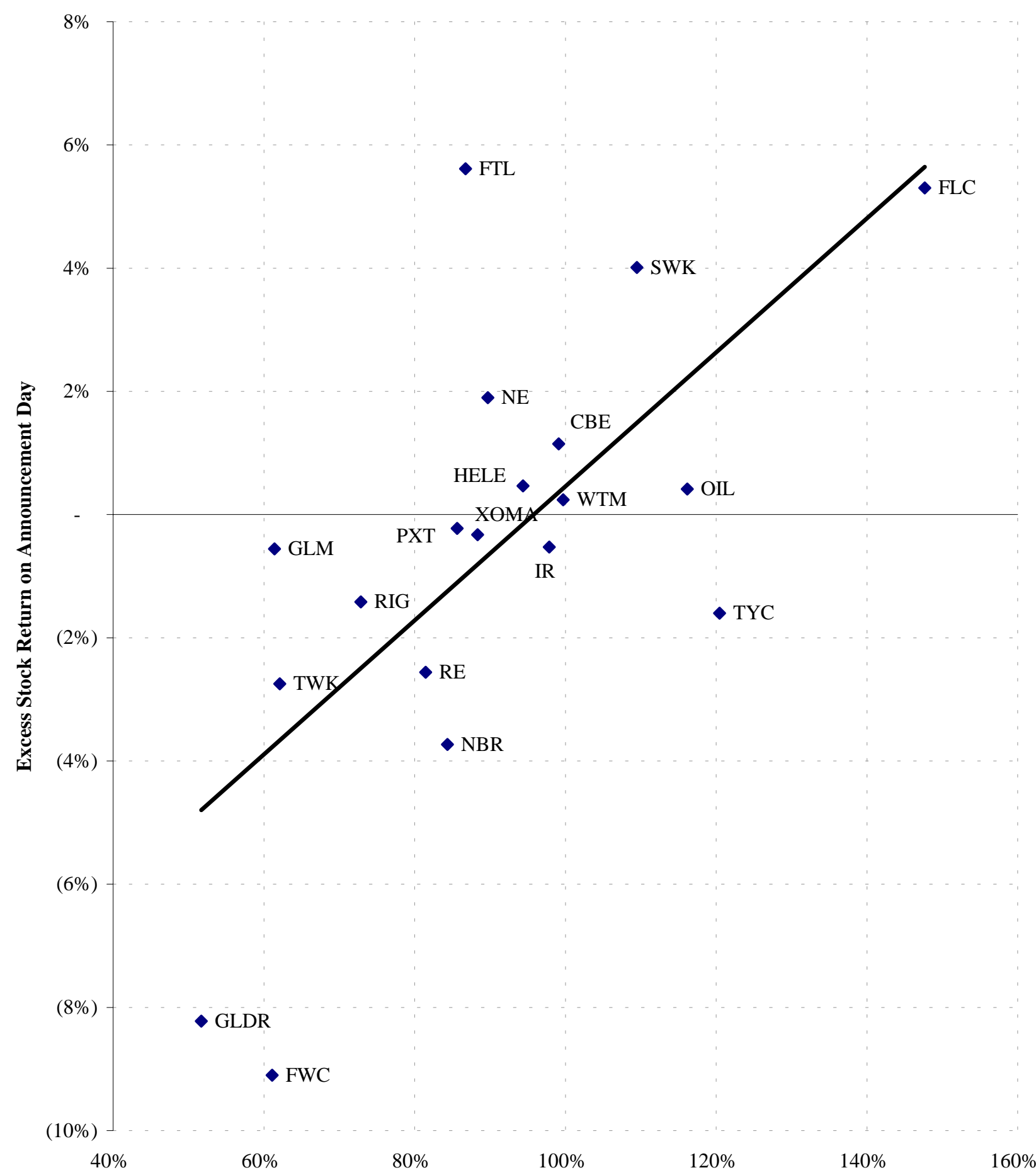

Ratio of Share Price on Day before Inversion Announcements to Average Stock Prices during Year Prior to Inversions

Note: The vertical axis measures the differences between stock returns and S\&P 500 index returns on inversion announcement days. The horizontal axis measures the ratio of share prices on the day before inversion announcements to volume-weighted average stock prices during the prior year. The line is the regression line for this relationship, as reported in column one of Table 4. 
Figure 7:

The Relationship between Excess Returns and Financial and Operating Characteristics of Corporate Expatriates
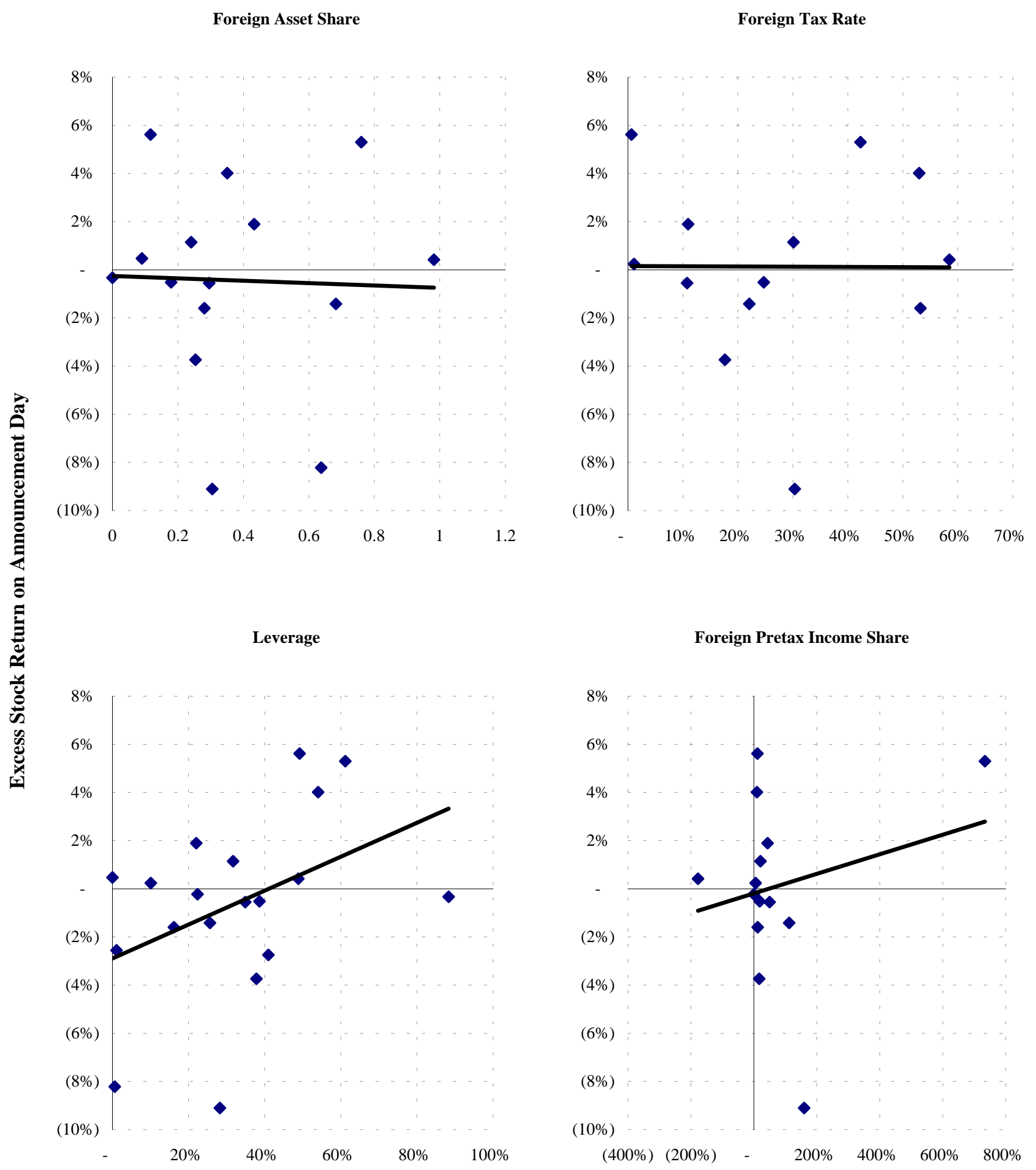

Note: The vertical axes measures the differences between stock returns and S\&P 500 index returns on inversion announcements days. The horizontal axes measure selected characteristics of inverting corporations. The lines are the regression lines for these relationships, as reported in columns two through five of Table 4. 
Table 1:

Corporate Expatriates, 1982-2002

\begin{tabular}{|c|c|c|c|c|c|}
\hline Company (Ticker) & $\begin{array}{l}\text { Announce } \\
\text { Date }\end{array}$ & Destination & $\begin{array}{c}\text { Transaction } \\
\text { Detail } \\
\end{array}$ & $\begin{array}{l}\text { Market Val. } \\
\text { At Annc. }\end{array}$ & $\begin{array}{c}\text { Description } \\
\end{array}$ \\
\hline Mcdermott (MDR) (a) & $2 / 10 / 1983$ & Panama & $\begin{array}{l}\text { Taxable Stock } \\
\text { Transfer }\end{array}$ & 727 & $\begin{array}{l}\text { McDermott builds deepwater and subsea oil and gas production facilities as well as nuclear reactor } \\
\text { components for the U.S. Navy and industrial equipment such as heat exchangers. A separate } \\
\text { subsidiary making power generation systems has filed for Chapter } 11 \text { protection because of asbestos } \\
\text { liabilities. }\end{array}$ \\
\hline Helen Of Troy (HELE) & $12 / 30 / 1993$ & Bermuda & $\begin{array}{l}\text { Taxable Stock } \\
\text { Transfer }\end{array}$ & 104 & $\begin{array}{l}\text { Helen of Troy sells licensed personal care products and accessories under the Vidal Sassoon and } \\
\text { Revlon brand names, as well its own WIGO, Karina, and Helen of Troy brands. Hair care items } \\
\text { include hair dryers, curling irons, brushes, rollers, and mirrors; other products include women's } \\
\text { shavers and foot massagers (Dr. Scholl's, Carel, Hotspa). }\end{array}$ \\
\hline Triton Energy (OIL) & 2/8/1996 & Cayman & $\begin{array}{l}\text { Taxable Stock } \\
\text { Transfer }\end{array}$ & 1,945 & $\begin{array}{l}\text { Triton Energy Limited is a Dallas-based international oil and gas exploration and production } \\
\text { company with major oil and gas assets in West Africa, Latin America and Southeast Asia. }\end{array}$ \\
\hline $\begin{array}{l}\text { Chicago Bridge \& Iron (CBI) } \\
\text { (a) }\end{array}$ & $12 / 18 / 1996$ & Netherlands & Subsidiary IPO & na & $\begin{array}{l}\text { Chicago Bridge \& Iron makes flat-bottom tanks, cryogenic tanks, pressure vessels, natural gas } \\
\text { processing plants, and elevated tanks for the petroleum, chemical, and water industries. }\end{array}$ \\
\hline Tyco (TYC) & $3 / 17 / 1997$ & Bermuda & $\begin{array}{l}\text { Taxable Stock } \\
\text { Transfer } \\
\text { (M\&A related) }\end{array}$ & 9,713 & $\begin{array}{l}\text { Conglomerate Tyco International's makes electrical connectors, conduits, and printed circuit boards; } \\
\text { security and fire-protection systems; healthcare products (bandages, crutches, and respiratory care } \\
\text { equipment); undersea fiber-optic cable; and offers financial services through CIT Group. }\end{array}$ \\
\hline $\begin{array}{l}\text { Santa Fe International (GSF) } \\
\text { (a) }\end{array}$ & $6 / 1 / 1997$ & Cayman & & na & $\begin{array}{l}\text { GlobalSantaFe is a leading offshore drilling contractor and was formed by the combination of Global } \\
\text { Marine and Santa Fe Internation. The company provides both turnkey drilling and drilling } \\
\text { management services. Government-owned Kuwait Petroleum owns } 29 \% \text { of GlobalSantaFe. }\end{array}$ \\
\hline Fruit Of The Loom (FTL) & $2 / 11 / 1998$ & Cayman & $\begin{array}{l}\text { Taxable Stock } \\
\text { Transfer }\end{array}$ & 1,823 & $\begin{array}{l}\text { Apparel maker, Fruit of the Loom, provides mostly basic underwear but other products include } \\
\text { activewear, casual wear, and children's underwear sold under the brand names Funpals, Fungals, and } \\
\text { Underoos. Berkshire Hathaway rescued the company from bankruptcy in } 2001 \text {. }\end{array}$ \\
\hline Playstar (a) & $5 / 5 / 1998$ & Antigua & F-Reorg. & na & $\begin{array}{l}\text { PlayStar Corporation, an Internet gaming and gambling startup, operates an online cyber-casino } \\
\text { where players can wager using a point system of virtual chips purchased via credit card in such games } \\
\text { of chance as blackjack, draw poker, baccarat, and roulette. The company licenses its games to other } \\
\text { online casino operators and hopes to license sports pool software to third parties. }\end{array}$ \\
\hline Gold Reserve (GLDR) & $11 / 24 / 1998$ & Canada & $\begin{array}{l}\text { Taxable Stock } \\
\text { Transfer }\end{array}$ & 27 & $\begin{array}{l}\text { Gold Reserve's primary asset is the Brisas mine, which contains an estimated } 9.9 \text { million ounces of } \\
\text { gold and about } 1.1 \text { billion pounds of copper. Gold Reserve has agreed to combine the Brisas project } \\
\text { with the neighboring Las Cristinas property (owned by Placer Dome and the Venezuelan government) } \\
\text { to form the world's sixth-largest gold mine. }\end{array}$ \\
\hline
\end{tabular}


Table 1:

Corporate Expatriates, 1982-2002

\begin{tabular}{|c|c|c|c|c|c|}
\hline Company (Ticker) & $\begin{array}{l}\text { Announce } \\
\text { Date }\end{array}$ & Destination & $\begin{array}{c}\text { Transaction } \\
\text { Detail }\end{array}$ & $\begin{array}{l}\text { Market Val. } \\
\text { At Annc. }\end{array}$ & Description \\
\hline Xoma (XOMA) & $11 / 24 / 1998$ & Bermuda & Asset & 160 & $\begin{array}{l}\text { XOMA, a drug developer, is working closely with Baxter International and Genentech on treatments } \\
\text { for childhood meningococcemia, Crohn's disease, rheumatoid arthritis, head and neck cancer therapy } \\
\text { and a vascular inflammation fighter. }\end{array}$ \\
\hline Transocean (RIG) & $3 / 15 / 1999$ & Cayman & $\begin{array}{l}\text { Taxable Stock } \\
\text { Transfer (b) }\end{array}$ & 2,539 & $\begin{array}{l}\text { Transocean, one of the world's leading offshore drilling contractors, specializes in deepwater drilling. } \\
\text { The company was formed in } 1999 \text { when Transocean Offshore merged with Sedco Forex, which had } \\
\text { been spun off from Schlumberger. It has expanded with the acquisition of rival R\&B Falcon. }\end{array}$ \\
\hline PXRE (PXT) & 7/7/1999 & Bermuda & $\begin{array}{l}\text { Taxable Stock } \\
\text { Transfer }\end{array}$ & 223 & $\begin{array}{l}\text { PXRE Group provides reinsurance to primary insurers and other reinsurers on commercial and } \\
\text { personal property and casualty risks, as well as marine and aviation risks. PXRE does some } 75 \% \text { of } \\
\text { its business internationally. }\end{array}$ \\
\hline Everest Reinsurance (RE) & 9/17/1999 & Bermuda & $\begin{array}{l}\text { Taxable Stock } \\
\text { Transfer }\end{array}$ & 1,311 & $\begin{array}{l}\text { Everest Re Group underwrites property/casualty reinsurance and offers property/casualty, marine, } \\
\text { aviation, surety, medical malpractice, directors and officers liability, and professional errors and } \\
\text { omissions liability coverages. Everest Re markets to U.S. and international insurance companies } \\
\text { directly and through independent brokers. }\end{array}$ \\
\hline $\begin{array}{l}\text { White Mountain Insurance } \\
\text { (WTM) }\end{array}$ & 9/23/1999 & Bermuda & Asset & 675 & $\begin{array}{l}\text { White Mountains Insurance Group operates a reinsurance company (Folksamerica) and provides } \\
\text { property and casualty insurance (mostly auto) through such subsidiaries as American Centennial, } \\
\text { Peninsula Insurance, and Waterford Insurance. }\end{array}$ \\
\hline Trenwick (TWK) & $12 / 19 / 1999$ & Bermuda & $\begin{array}{l}\text { Asset }(\mathrm{M} \& \mathrm{~A} \\
\text { related })\end{array}$ & 279 & $\begin{array}{l}\text { Trenwick Group operates Trenwick America Reinsurance (treaty reinsurance for U.S. property \& } \\
\text { casualty), Trenwick International (treaty and facultative reinsurance), Canterbury Financial Group } \\
\text { (reinsures U.S. property \& casualty coverage), LaSalle Re (catastrophe coverage), and Chartwell } \\
\text { Managing Agents (member of Lloyd's of London). }\end{array}$ \\
\hline Applied Power (a) & $3 / 10 / 2000$ & Bermuda & $\begin{array}{l}\text { Subsidiary } \\
\text { Spin-off }\end{array}$ & na & $\begin{array}{l}\text { Applied Power, a spinoff of industrial tools maker, Actuant (formerly Applied Power), specializes in } \\
\text { making enclosures that for electronic systems. It provides design, engineering, and assembly services } \\
\text { to customers such as Cisco, IBM, Nokia, and Sun Microsystems. }\end{array}$ \\
\hline R\&B Falcon (FLC) & $8 / 21 / 2000$ & Cayman & $\begin{array}{l}\text { Acquired by } \\
\text { Foreign Entity }\end{array}$ & 4,906 & $\begin{array}{l}\text { R\&B Falcon Corporation operates the world's largest fleet of marine-based drilling rigs servicing the } \\
\text { international oil and gas industry. R\&B Falcon also provides turnkey and integrated services and } \\
\text { operates mobile production units, internationally based land rigs and an offshore towing business. }\end{array}$ \\
\hline Foster Wheeler (FWC) & $11 / 29 / 2000$ & Bermuda & $\begin{array}{l}\text { Taxable Stock } \\
\text { Transfer (b) }\end{array}$ & 183 & $\begin{array}{l}\text { Foster Wheeler operates two businesses. (1) The Engineering and Construction group designs and } \\
\text { builds chemical, petroleum, and industrial plants and provides environmental remediation services. } \\
\text { (2) The Energy Equipment group makes steam generating units and related equipment for power and } \\
\text { industrial plants, and also builds, owns, and leases cogeneration and independent power projects. }\end{array}$ \\
\hline
\end{tabular}


Table 1:

Corporate Expatriates, 1982-2002

\begin{tabular}{|c|c|c|c|c|c|}
\hline Company (Ticker) & $\begin{array}{l}\text { Announce } \\
\text { Date }\end{array}$ & Destination & $\begin{array}{l}\text { Transaction } \\
\text { Detail }\end{array}$ & $\begin{array}{l}\text { Market Val. } \\
\text { At Annc. }\end{array}$ & Description \\
\hline Cooper Industries (CBE) & $6 / 11 / 2001$ & Bermuda & $\begin{array}{l}\text { Taxable Stock } \\
\text { Transfer }\end{array}$ & 3,551 & $\begin{array}{l}\text { Cooper Industries makes electrical products, tools, hardware, and metal support products. The } \\
\text { company's electrical products (more than } 80 \% \text { of sales) include electrical and circuit-protection } \\
\text { devices, residential and industrial lighting, and electrical power and distribution products for use by } \\
\text { utility companies. }\end{array}$ \\
\hline Global Marine (GLM) & $9 / 4 / 2001$ & Cayman & $\begin{array}{l}\text { Taxable Stock } \\
\text { Transfer } \\
\text { (M\&A related) }\end{array}$ & 2,667 & $\begin{array}{l}\text { Houston-based Global Marine is one of the largest offshore drilling contractors with an active fleet of } \\
\text { more than } 30 \text { mobile rigs worldwide. In addition, the company is the world's largest provider of } \\
\text { offshore drilling management services. }\end{array}$ \\
\hline Ingersoll Rand (IR) & $10 / 16 / 2001$ & Bermuda & $\begin{array}{l}\text { Taxable Stock } \\
\text { Transfer }\end{array}$ & 6,719 & $\begin{array}{l}\text { Ingersoll-Rand, known for having made the tools and machinery that carved the faces on Mount } \\
\text { Rushmore, makes refrigeration equipment, locks and security systems, construction and industrial } \\
\text { equipment used for infrastructure improvements, and industrial equipment used to increase } \\
\text { productivity. }\end{array}$ \\
\hline Nabors Industries (NBR) & $1 / 2 / 2002$ & Bermuda & $\begin{array}{l}\text { Taxable Stock } \\
\text { Transfer }\end{array}$ & 4,657 & $\begin{array}{l}\text { Nabors Industries is one of the world's largest drilling contractors, with more than } 530 \text { land drilling } \\
\text { rigs and } 930 \text { land workover rigs and includes } 44 \text { offshore platform rigs, } 15 \text { jack-ups, and three barge } \\
\text { drilling rigs. Nabors also provides oil field hauling, engineering, and construction services. }\end{array}$ \\
\hline Noble Drilling (NE) & $1 / 31 / 2002$ & Cayman & $\begin{array}{l}\text { Taxable Stock } \\
\text { Transfer }\end{array}$ & 4,223 & $\begin{array}{l}\text { Noble Drilling provides deepwater oil and gas contract drilling services through a fleet of } 53 \text { offshore } \\
\text { rigs, including three submersibles, three drillships, } 13 \text { semisubmersibles, and } 34 \text { jack-ups. Subsidiary } \\
\text { Triton Engineering provides engineering and consulting services. }\end{array}$ \\
\hline Stanley Tools (SWK) & $2 / 8 / 2002$ & Bermuda & $\begin{array}{l}\text { Taxable Stock } \\
\text { Transfer }\end{array}$ & 3,688 & $\begin{array}{l}\text { The Stanley Works is the leading toolmaker in the US, making hand tools, mechanics' tools, } \\
\text { pneumatic tools, and hydraulic tools, as well as hardware and a variety of door products. Its brand } \\
\text { names include Bostitch, Jensen, Husky, Stanley, and Vidmar. }\end{array}$ \\
\hline \multicolumn{6}{|c|}{ NON-INVERSION EXPATRIATIONS } \\
\hline Seagate Technology (a) & $4 / 20 / 2001$ & Cayman & "Ab Initio" & na & $\begin{array}{l}\text { Seagate Technology is a leading independent maker of storage drives for computers. It makes disk } \\
\text { and tape drives used in systems ranging from personal computers to high-end servers. }\end{array}$ \\
\hline Accenture (a) & $7 / 19 / 2001$ & Bermuda & "Ab Initio" & na & $\begin{array}{l}\text { Accenture is the former consulting arm of Arthur Andersen. It is the world's largest management and } \\
\text { technology consulting firm and offers its multinational clientele such services as strategic planning, } \\
\text { data system design and implementation, customer service system consulting. }\end{array}$ \\
\hline
\end{tabular}


Table 2:

Financial and Operating Details from Stanley Works, 2002

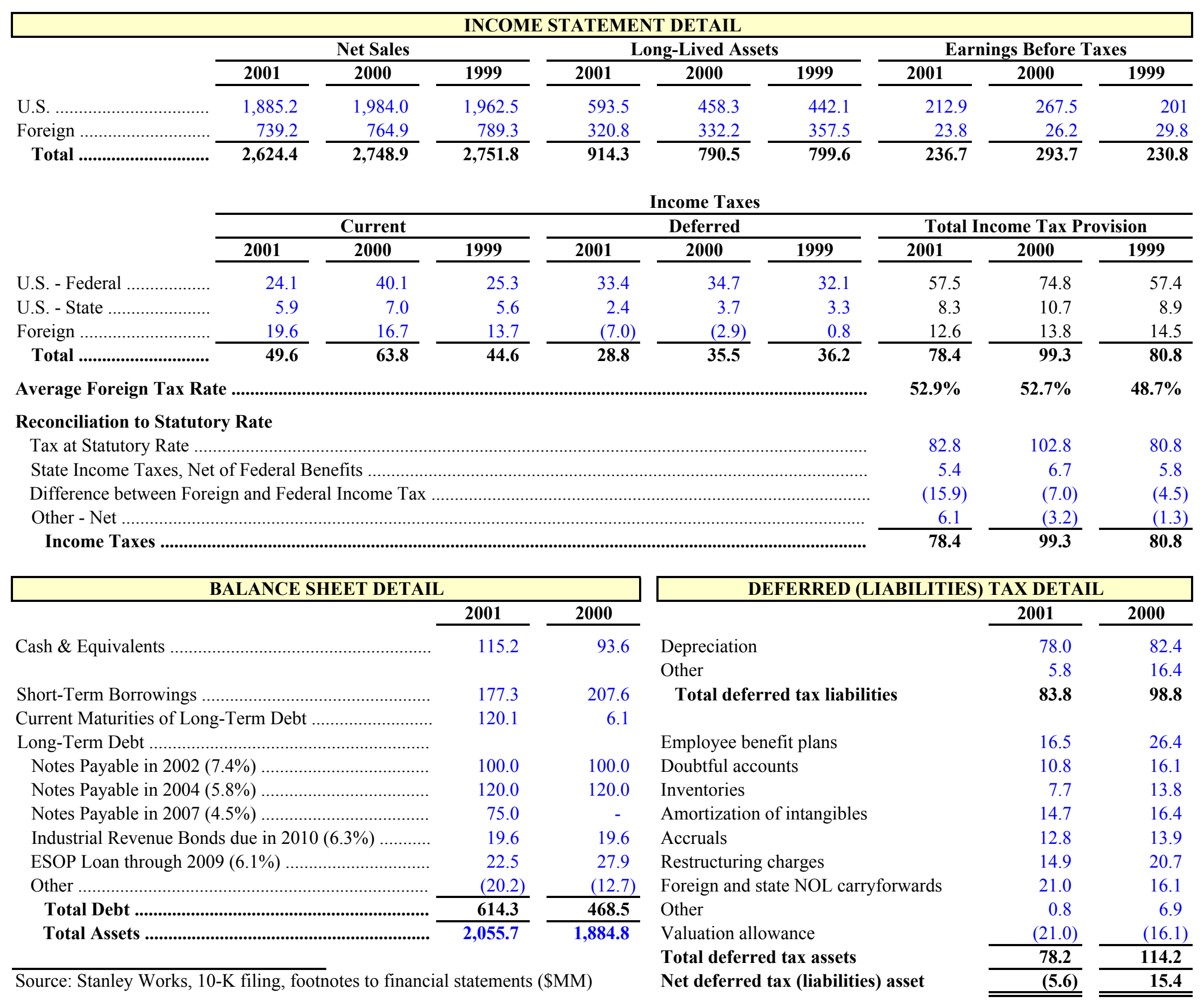


Table 3:

Determinants of Expatriations

(1)

-6.5493
$(0.6507)$
0.4813
$(0.0885)$

Foreign asset share

Leverage

Constant

Log Total Assets

Average foreign tax rate

(2)

(3)

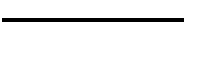

$-6.6944$

(0.8039)

$-7.5456$

(1.1487)

0.3408

0.6142

(0.1365)

0.5010

(4)

(5)

(6)

(7)

(0.1365)

\subsection{6}

(0.9484)

3.3517

(1.1488)

(0.1107)

$-5.5038$

$-6.6155$

$-6.7861$

(0.6925)

(1.0592)

(1.3899)

0.3640

0.4936

(0.1480)

(0.1658)

4.9915

4.8180

(1.2015)

(1.5524)

0.5964
$(0.2208)$

1.1070

0.9128

(0.4933)

$-2.1893$

$-6.5565$

(1.4794)

0.4790

(0.1716)

4.7076

(1.5707)

(0.5305)
$-2.6535$
(1.7897)

$-2.6898$

(2.1100)

(2.4759)

\section{Interaction of Leverage and Average Foreign Tax Rate}

No. of Obs.

663

663

340

215

340

113

Log Likelihood

$-73.5496$

$-58.7318 \quad-56.1250$

$-43.6553$

$-46.0401$

$-28.8871$

$-28.8379$

NOTE: The table reports estimated coefficients from logit regressions in which the dependent variable equals one if a firm announces plans to expatriate at any time and equals zero otherwise. Log Total Assets is the log of the book value of total assets. Leverage is the ratio of the book value of long term debt to the book value of total assets. Foreign Asset Share is the share of all assets held abroad. Average foreign tax rate is the average tax rate paid on foreign income. The interaction term is the product of leverage and the average foreign tax rate. All variables are measured as of yearend 1997. Robust standard errors are presented in parentheses. 
Table 4:

Excess Returns from Expatriations

\begin{tabular}{|c|c|c|c|c|c|c|c|c|c|}
\hline & (1) & (2) & (3) & (4) & (5) & (6) & (7) & (8) & (9) \\
\hline Constant & $\begin{array}{l}-0.1042 \\
(0.0268)\end{array}$ & $\begin{array}{l}-0.0289 \\
(0.0143)\end{array}$ & $\begin{array}{l}-0.0019 \\
(0.0108)\end{array}$ & $\begin{array}{l}-0.0026 \\
(0.0194)\end{array}$ & $\begin{array}{c}0.0015 \\
(0.0199)\end{array}$ & $\begin{array}{l}-0.1062 \\
(0.0264)\end{array}$ & $\begin{array}{l}-0.0990 \\
(0.0409)\end{array}$ & $\begin{array}{l}-0.1080 \\
(0.0475)\end{array}$ & $\begin{array}{l}-0.1421 \\
(0.0408)\end{array}$ \\
\hline $\begin{array}{l}\text { Ratio of announcement day } \\
\text { stock price to weighted average }\end{array}$ & $\begin{array}{c}0.1088 \\
(0.0289)\end{array}$ & & & & & $\begin{array}{c}0.0970 \\
(0.0299)\end{array}$ & $\begin{array}{c}0.0752 \\
(0.0440)\end{array}$ & $\begin{array}{c}0.0743 \\
(0.0541)\end{array}$ & $\begin{array}{c}0.1582 \\
(0.0570)\end{array}$ \\
\hline Leverage (debt to total assets) & & $\begin{array}{c}0.0704 \\
(0.0348)\end{array}$ & & & & $\begin{array}{c}0.0389 \\
(0.0310)\end{array}$ & $\begin{array}{c}0.0868 \\
(0.0681)\end{array}$ & $\begin{array}{c}0.1336 \\
(0.0940)\end{array}$ & $\begin{array}{c}0.1076 \\
(0.0757)\end{array}$ \\
\hline Foreign pretax income share & & & $\begin{array}{c}0.0041 \\
(0.0052)\end{array}$ & & & & $\begin{array}{l}-0.0018 \\
(0.0050)\end{array}$ & $\begin{array}{l}-0.0016 \\
(0.0056)\end{array}$ & $\begin{array}{l}-0.0055 \\
(0.0048)\end{array}$ \\
\hline Foreign asset share & & & & $\begin{array}{l}-0.0049 \\
(0.0423)\end{array}$ & & & & $\begin{array}{l}-0.0255 \\
(0.0465)\end{array}$ & $\begin{array}{c}0.0119 \\
(0.0406)\end{array}$ \\
\hline Average foreign tax rate & & & & & $\begin{array}{l}-0.0007 \\
(0.0600)\end{array}$ & & & & $\begin{array}{l}-0.1636 \\
(0.0729)\end{array}$ \\
\hline No. of Obs. & 19 & 19 & 14 & 15 & 13 & 19 & 14 & 12 & 12 \\
\hline Adjusted R-Squared & 0.4233 & 0.1288 & -0.0306 & -0.0758 & -0.0909 & 0.4422 & 0.2454 & 0.1939 & 0.4885 \\
\hline
\end{tabular}

NOTE: The table presents estimated coefficients from OLS regressions in which the dependent variable is the difference between stock returns and S\&P 500 index returns on inversion announcement days. The ratio of announcement day stock price to weighted average price uses the volume-weighted average price over the year prior to the inversion announcement.

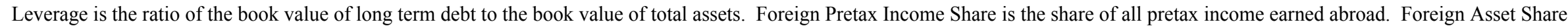
is the share of all assets held abroad. Average foreign tax rate is the average tax rate paid on foreign income. Standard errors are in parentheses. 